\title{
Article \\ Simultaneous Biochemical and Physiological Responses of the Roots and Leaves of Pancratium maritimum (Amaryllidaceae) to Mild Salt Stress
}

\author{
Simona Carfagna ${ }^{1}(\mathbb{D})$, Giovanna Salbitani ${ }^{1}\left(\mathbb{D}\right.$, Michele Innangi $^{2}\left(\mathbb{D}\right.$, Bruno Menale $^{1}$, Olga De Castro $^{1}$, \\ Catello Di Martino $^{3, *}$ and Thomas W. Crawford Jr. 4 (D)
}

1 Dipartimento di Biologia, Università degli Studi di Napoli Federico II, 80126 Napoli, Italy; simona.carfagna@unina.it (S.C.); giovanna.salbitani@unina.it (G.S.); bruno.menale@unina.it (B.M.); olga.decastro@unina.it (O.D.C.)

2 Dipartimento di Scienze e Tecnologie Ambientali, Biologiche e Farmaceutiche, Università degli Studi della Campania Luigi Vanvitelli, 81100 Caserta, Italy; michele.innangi@unina.it

3 Dipartimento di Agricoltura, Ambiente ed Alimenti, Università degli Studi del Molise, 86100 Campobasso, Italy

4 Global Agronomy, LLC, Marana, AZ 85658, USA; globalagronomy@gmail.com

* Correspondence: lello.dimartino@unimol.it

check for updates

Citation: Carfagna, S.; Salbitani, G.; Innangi, M.; Menale, B.; De Castro, O.; Di Martino, C.; Crawford, T.W., Jr. Simultaneous Biochemical and Physiological Responses of the Roots and Leaves of Pancratium maritimum (Amaryllidaceae) to Mild Salt Stress. Plants 2021, 10, 345. https://doi.org/ $10.3390 /$ plants10020345

Academic Editor: Mirza Hasanuzzaman

Received: 22 December 2020

Accepted: 8 February 2021

Published: 11 February 2021

Publisher's Note: MDPI stays neutral with regard to jurisdictional claims in published maps and institutional affiliations.

Copyright: (c) 2021 by the authors. Licensee MDPI, Basel, Switzerland. This article is an open access article distributed under the terms and conditions of the Creative Commons Attribution (CC BY) license (https:// creativecommons.org/licenses/by/ $4.0 /)$.

\begin{abstract}
Pancratium maritimum (Amaryllidaceae) is a bulbous geophyte growing on coastal sands. In this study, we investigated changes in concentrations of metabolites in the root and leaf tissue of P. maritimum in response to mild salt stress. Changes in concentrations of osmolytes, glutathione, sodium, mineral nutrients, enzymes, and other compounds in the leaves and roots were measured at 0,3 , and 10 days during a 10-day exposure to two levels of mild salt stress, $50 \mathrm{mM} \mathrm{NaCl}$ or $100 \mathrm{mM} \mathrm{NaCl}$ in sandy soil from where the plants were collected in dunes near Cuma, Italy. Sodium accumulated in the roots, and relatively little was translocated to the leaves. At both concentrations of $\mathrm{NaCl}$, higher values of the concentrations of oxidized glutathione disulfide (GSSG), compared to reduced glutathione (GSH), in roots and leaves were associated with salt tolerance. The concentration of proline increased more in the leaves than in the roots, and glycine betaine increased in both roots and leaves. Differences in the accumulation of organic osmolytes and electron donors synthesized in both leaves and roots demonstrate that osmoregulatory and electrical responses occur in these organs of P. maritimum under mild salt stress.
\end{abstract}

Keywords: amino acids; glutathione; OAS-TL; osmolytes; mineral nutrients; nucleotides

\section{Introduction}

Due to their sessile nature, plants undergo biotic and abiotic stress. By evolution of their metabolism, plants of Pancratium maritimum L. (Amaryllidaceae) have developed metabolic responses to mitigate environmental stresses and anatomical responses such as the bulb to protect sensitive parts of the plant, the leaves, and flowers, from extreme salt stress. Among abiotic stresses, salinity is a major constraint that restricts the growth and development of plants through, i.e., osmotic stress, cytotoxicity, nutritional imbalance, and oxidative stress [1]. Besides stressing plants in natural, saline environments, salinity can severely limit yield and productivity of crops, especially in the most productive areas of the world, such as the Mediterranean basin [2,3].

Halophytes are salt-resistant or salt-tolerant plants that complete their life cycle in saline habitats [4]. The tolerance of salinity is a complex phenomenon that involves various biochemical mechanisms and physiological adaptations, and P. maritimum represents an ideal model to understand metabolism contributing to resistance or tolerance to salt stress. While there are halophytes that can grow under salinity as extreme as $500 \mathrm{mM} \mathrm{NaCl}$ 
( seawater salinity), optimal growth of many terrestrial, dicotyledonous geophytes that are exposed to mild salinity occurs within the range of concentrations of 50-250 $\mathrm{mM} \mathrm{NaCl}$ [5-7].

P. maritimum is a bulbous, perennial geophyte typical of the Mediterranean region from the Black Sea to part of the Atlantic coast [8,9]. It grows wild on coastal sands and on coastal dunes, where mild salinity $(\sim 50-100 \mathrm{mM} \mathrm{NaCl})$ is a key aspect of its optimal habitat. Coastal dune vegetation is exposed to severe atmospheric and edaphic stresses, which have caused these plants to evolve several mechanisms to counteract the stresses in order to grow and reproduce [10].

Although there is evidence that all plants, both sensitive and tolerant, use similar mechanisms in response to high salinity, little is presently known about the simultaneous mechanisms of salt tolerance of plants in their natural habitats. Salt tolerance of halophytes has been shown to be dependent on their capacity to compartmentalize toxic ions in the vacuole and to accumulate osmoprotectants, that are compatible solutes, in the cytoplasm [1,11]. Khan et al. [12] reported that the macronutrient sulfur is essential not only for plant growth but also for tolerance to salt stress. Many studies have investigated various mechanisms that protect plant cells from toxicity in the presence of high salinity $[13,14]$, but these studies have not investigated S-containing compounds involved in salt stress responses. In all plants, essential compounds such as glutathione (reduced form, GSH; oxidized form, GSSG), hormones (e.g., ethylene, polyamines), vitamins, cofactors (e.g., biotin, thiamine, CoenzymeA), and many other secondary products are derived from the S-amino acid cysteine (Cys) [15-17]. Cys is required for the biosynthesis of abscisic acid (ABA), the phytohormone regulating responses to many abiotic stresses [18], and synthesis of Cys increases in many plants in response to various abiotic stresses [19-21].

The present study investigates, for the first time, roles of glutathione and O-acetylserine(thio)lyase (OAS-TL, EC 4.2.99.8), both involved in sulfur metabolism, in response to mild salt stress in a bulbous plant typically subjected to wide fluctuations of salinity in its natural environment. OAS-TL catalyzes Cys synthesis from sulfide and O-acetylserine, so we determined the enzymatic activity of OAS-TL in leaves and roots of P. maritimum within a range of salinity typical of its edaphic environment [9].

Therefore, the variable conditions of time of exposure and concentration of salt were applied in our experiments to present $P$. maritimum with a range of mild salt stress from a minimum of exposure to $50 \mathrm{mM} \mathrm{NaCl}$ for 3 days (d) to a maximum of exposure to $100 \mathrm{mM}$ $\mathrm{NaCl}$ for 10 days. Changes in the concentration of some metabolites, such as osmolytes and glutathione, measured in different regimes of mild salt-stress and in the roots and leaves of the plants are described and discussed.

\section{Results}

\subsection{Concentrations of Pyridine Nucleotides and Glutathione}

Salt treatment with $50 \mathrm{mM}$ and $100 \mathrm{mM} \mathrm{NaCl}$ provoked a slight increase in $\mathrm{NADP}^{+}$ and NADPH contents in roots and greater concentrations in the leaves. In both organs, there was a progressive decrease of the $\mathrm{NADP}^{+} / \mathrm{NADPH}$ redox ratio from about 2 to 1.25 in P. maritimum plants treated for $10 \mathrm{~d}$ with $100 \mathrm{mM} \mathrm{NaCl}$ (Table. 1). GSH content increased as much as $\sim 3.2$-fold in the leaves of plants treated with $50 \mathrm{mM} \mathrm{NaCl}$ after 3 days but there was no evidence of change in GSH concentration in the roots; at $10 \mathrm{~d}$ the GSH levels in the roots decreased by $80 \%$ compared to the control. The reduction in GSH concentration in the roots was more evident with the $100 \mathrm{mM} \mathrm{NaCl}$ treatment at both 3 and $10 \mathrm{~d}$ with a decrease of 80 and 70\% respect to the control, respectively (Figure 1A). In the leaves, however, the concentrations of GSH after $50 \mathrm{mM}$ treatment were always higher than the control. For example, at 3 ds after treatment, the GSH concentration reached 300\% more than the control, and then decreased to $20 \%$ more at 10 days. The $100 \mathrm{mM}$ treatment, however, resulted in a significant, albeit small, decrease in concentration of GSH in the leaves after 10 days with a reduction of $55 \%$ compared to the control. 

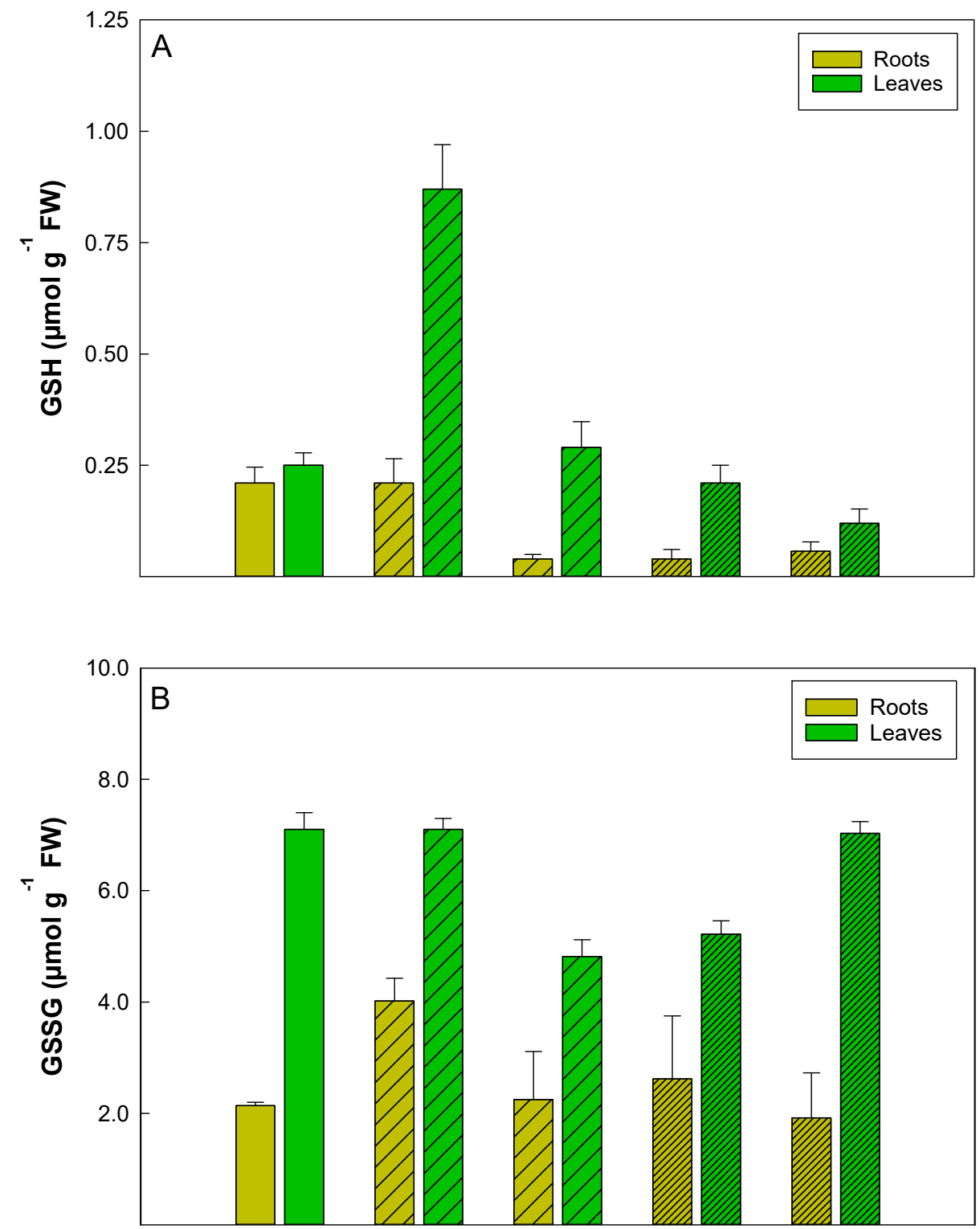

Figure 1. Glutathione (GSH) (A) and glutathione disulfide (GSSG) (B) concentrations ( $\left.\mu \mathrm{mol} \mathrm{g}^{-1} \mathrm{FW}\right)$ in roots (light green) and leaves (brilliant green) tissue of $P$. maritimum plants irrigated with $50 \mathrm{mM}$ (wide striped) and $100 \mathrm{mM}$ (narrow striped) of $\mathrm{NaCl}$ salt solution for 3 and 10 days. The values are means \pm SD of three replicates.

During the 10-day treatment with $100 \mathrm{mM} \mathrm{NaCl}$, the concentration of the GSSG in the leaves decreased and then returned to the level of control plants (Figure 1B). On the contrary, roots treated with $50 \mathrm{mM} \mathrm{NaCl}$ for $3 \mathrm{~d}$ accumulated more GSSG while the concentration of GSH was unchanged, with respect to the untreated plants. The concentrations of GSH and GSSG were greater in the leaves than in the roots with each $\mathrm{NaCl}$ treatment (Figure 2A,B). The concentrations of the oxidized compounds (GSSG and NADP ${ }^{+}$) were consistently greater than those of the corresponding reduced compounds (GSH and NADPH) for roots and leaves during $10 \mathrm{~d}$ for both $50 \mathrm{mM} \mathrm{NaCl}$ and $100 \mathrm{mM} \mathrm{NaCl}$, as estimated by regression analysis (Figure $2 \mathrm{C}-\mathrm{F}$ ). Although $\mathrm{NAD}^{+} / \mathrm{NADH}$ ratio continued to be greater than 1 for the entire duration of the experiment, after $10 \mathrm{~d}$ of treatment with $\mathrm{NaCl}$ it decreased to $50 \%$, both in the roots and leaves, indicating a proportionately greater increase in reduced NADH than oxidized NAD ${ }^{+}$(Table 1$)$. 


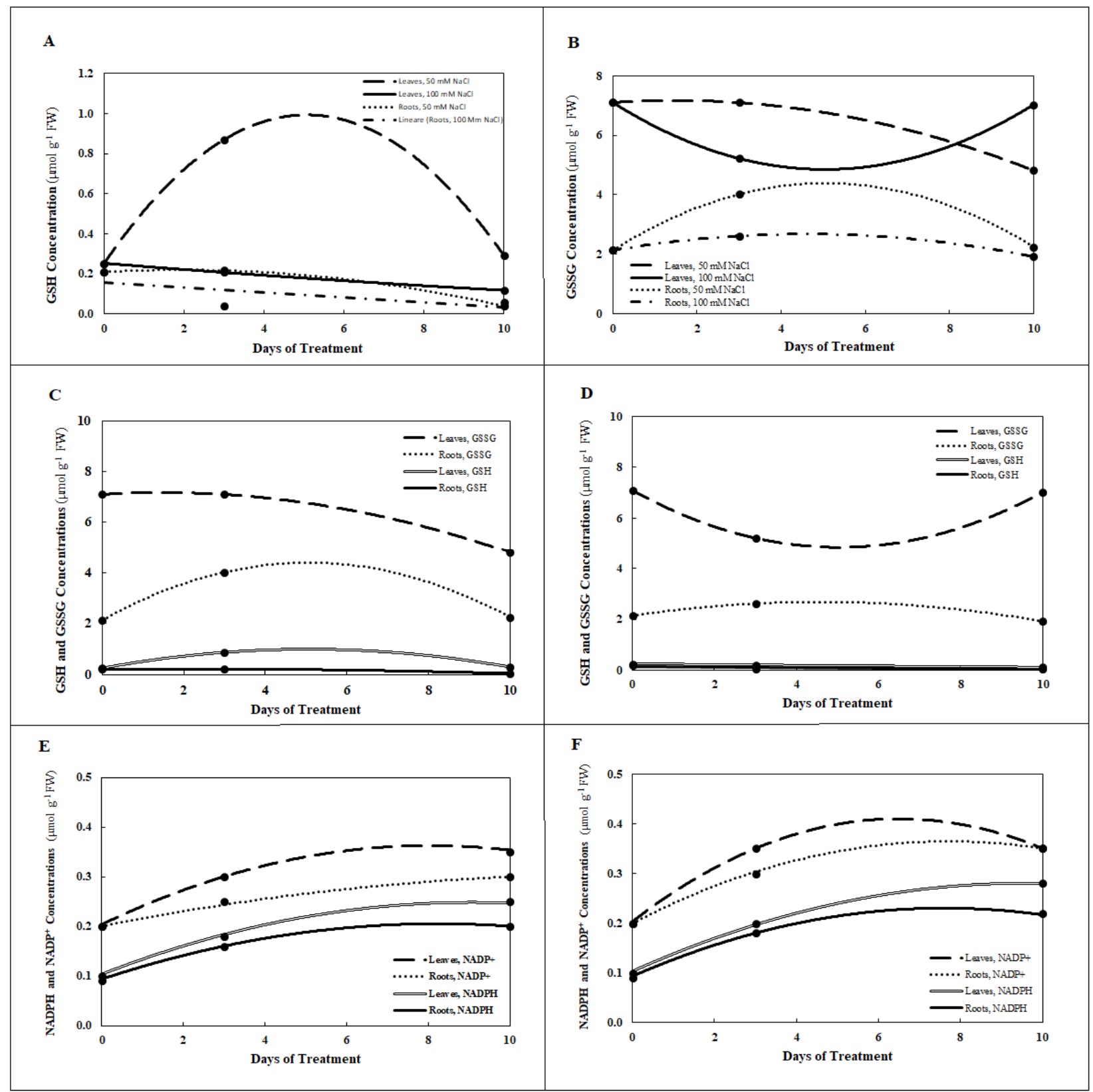

Figure 2. Estimates of concentration of reduced glutathione (GSH, A), oxidized glutathione (GSSG, B), GSH and GSSG in the roots and leaves treated with $50 \mathrm{mM} \mathrm{NaCl}(\mathbf{C})$, GSH and GSSG in the roots and leaves treated with $100 \mathrm{mM} \mathrm{NaCl}(\mathbf{D})$, and reduced nicotinamide adenine dinucleotide phosphate (NADPH, E), and oxidized nicotinamide adenine dinucleotide phosphate $\left(\mathrm{NADP}^{+}, \mathbf{F}\right)$ in roots and leaves of P. maritimum during 10 days of treatment with $50 \mathrm{mM} \mathrm{NaCl}(\mathbf{E})$ or $100 \mathrm{mM}$ $\mathrm{NaCl}(\mathbf{F})$. Black dots represent the mean of three replicates. 
Table 1. Pyridine nucleotides ( $\mu \mathrm{mol} \mathrm{g}{ }^{-1} \mathrm{FW}$ ) in roots and leaves tissue of $P$. maritimum plants irrigated with 50 and $100 \mathrm{mM}$ of $\mathrm{NaCl}$ salt solution for 3 and 10 days.

\begin{tabular}{|c|c|c|c|c|c|}
\hline & Control & $50 \mathrm{mM}$ & $\mathrm{NaCl}$ & $100 \mathrm{mM}$ & $\mathrm{NaCl}$ \\
\hline Days & 0 & 3 & 10 & 3 & 10 \\
\hline \multicolumn{6}{|c|}{$\begin{array}{c}\text { Roots } \\
\left(\mu \mathrm{mol} \mathrm{g}{ }^{-1} \mathrm{FW}\right)\end{array}$} \\
\hline $\mathrm{NADP}^{+}$ & $0.20 \pm 0.03^{\mathrm{Aa}}$ & $0.25 \pm 0.04^{\mathrm{Aa}}$ & $0.30 \pm 0.04^{\mathrm{Aa}}$ & $0.30 \pm 0.03^{\mathrm{Aa}}$ & $0.35 \pm 0.04^{\mathrm{Aa}}$ \\
\hline NADPH & $0.09 \pm 0.03^{\mathrm{Aa}}$ & $0.16 \pm 0.03^{\mathrm{Bb}}$ & $0.20 \pm 0.03^{\mathrm{Bb}}$ & $0.18 \pm 0.02^{\mathrm{Bb}}$ & $0.22 \pm 0.04^{\mathrm{Bb}}$ \\
\hline $\mathrm{NAD}^{+}$ & $0.40 \pm 0.03^{\mathrm{Aa}}$ & $0.55 \pm 0.04^{\mathrm{Ab}}$ & $0.60 \pm 0.04^{\mathrm{Ab}}$ & $0.55 \pm 0.04^{\mathrm{Ab}}$ & $0.65 \pm 0.04^{\mathrm{Ab}}$ \\
\hline $\mathrm{NADH}$ & $0.15 \pm 0.02^{\mathrm{Aa}}$ & $0.30 \pm 0.03^{\mathrm{Bb}}$ & $0.40 \pm 0.03^{\mathrm{Bb}}$ & $0.32 \pm 0.03^{\mathrm{Bb}}$ & $0.50 \pm 0.04^{\mathrm{Bc}}$ \\
\hline \multicolumn{6}{|c|}{$\begin{array}{c}\text { Leaves } \\
\left(\mu \mathrm{mol} \mathrm{g}{ }^{-1} \mathrm{FW}\right)\end{array}$} \\
\hline $\mathrm{NADP}^{+}$ & $0.20 \pm 0.03^{\mathrm{Aa}}$ & $0.30 \pm 0.03^{\mathrm{Ab}}$ & $0.35 \pm 0.02^{\mathrm{Ab}}$ & $0.35 \pm 0.03^{\mathrm{Ab}}$ & $0.35 \pm 0.02^{\mathrm{Ab}}$ \\
\hline NADPH & $0.10 \pm 0.03^{\mathrm{Aa}}$ & $0.18 \pm 0.03^{\mathrm{Ab}}$ & $0.25 \pm 0.003^{\mathrm{Ac}}$ & $0.20 \pm 0.02^{\mathrm{Ab}}$ & $0.28 \pm 0.03^{A c}$ \\
\hline $\mathrm{NAD}^{+}$ & $0.40 \pm 0.06^{\mathrm{Aa}}$ & $0.60 \pm 0.03^{\mathrm{Ab}}$ & $0.55 \pm 0.03^{\mathrm{Ab}}$ & $0.50 \pm 0.02^{\mathrm{Ab}}$ & $0.50 \pm 0.03^{\mathrm{Ab}}$ \\
\hline $\mathrm{NADH}$ & $0.18 \pm 0.03^{\mathrm{Aa}}$ & $0.40 \pm 0.02^{\mathrm{Ab}}$ & $0.35 \pm 0.03^{\mathrm{Ab}}$ & $0.38 \pm 0.03^{\mathrm{Ab}}$ & $0.42 \pm 0.03^{\mathrm{Ab}}$ \\
\hline
\end{tabular}

The values are means \pm SD of tree replicates and means marked by common letters are not statistically different at $p \leq 0.01$ (uppercase) or $p$ $\leq 0.05$ (small letters) for values in the same row, according to Scheffè's test performed between control and plants with different treatment.

\subsection{OAS-TL Activity and Concentration of Protein}

After $3 \mathrm{~d}$ of $50 \mathrm{mM} \mathrm{NaCl}$ treatment, the activity of OAS-TLs was enhanced strongly in the leaves and slightly in the roots. The $100 \mathrm{mM} \mathrm{NaCl}$ treatment resulted in a decrease in OAS-TL activity in the leaves at $3 \mathrm{~d}$, followed by an increase at $10 \mathrm{~d}$. In the roots, the $100 \mathrm{mM} \mathrm{NaCl}$ treatment slightly increased the activity of OAS-TLs at $3 \mathrm{~d}$, and then the activity decreased at $10 \mathrm{~d}$ (Figure 3 ).

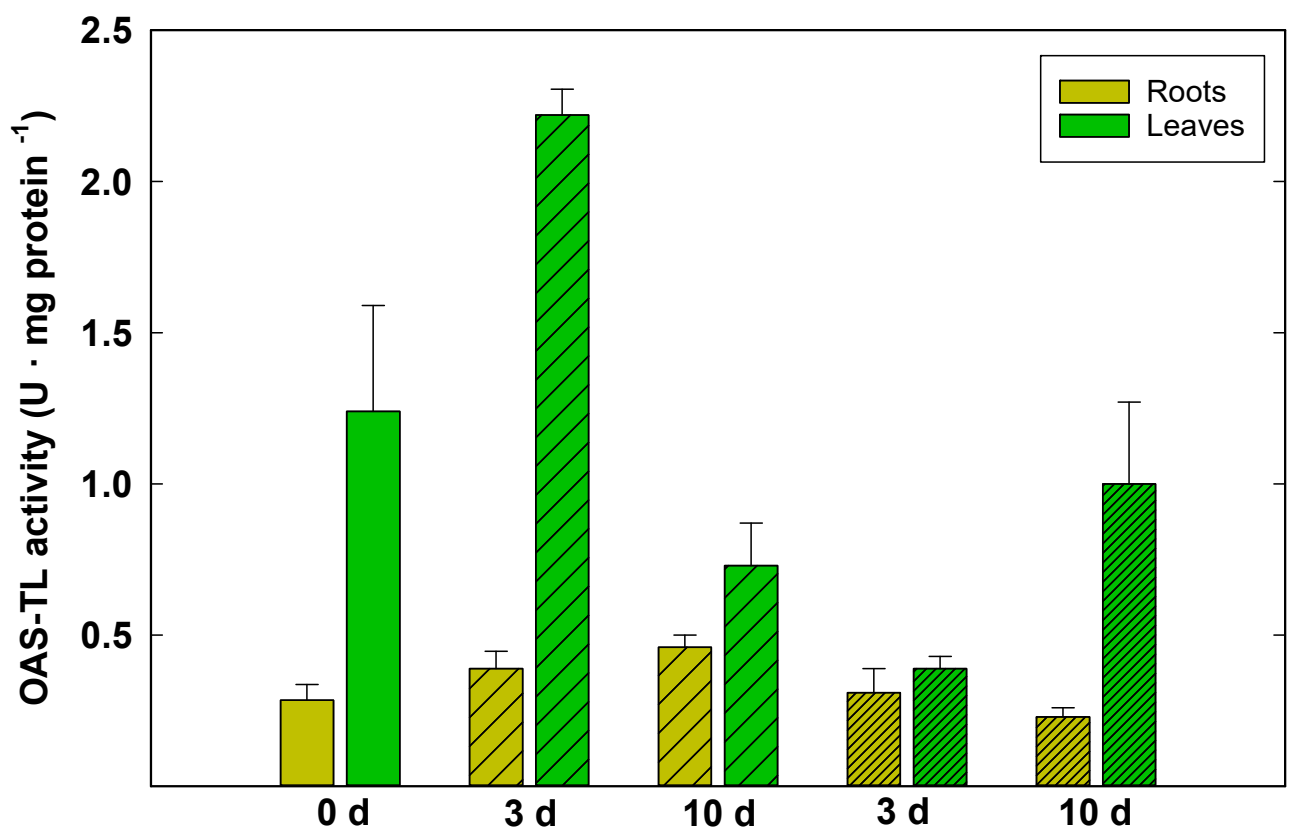

Figure 3. O-acetyl-1-serine(thiol)lyase (OAS-TL) activity ( $\mathrm{U} \mathrm{mg} \mathrm{protein}^{-1}$ ) in roots (light green) and leaves (brilliant green) of P. maritimum plants irrigated with $50 \mathrm{mM}$ (wide striped) and $100 \mathrm{mM}$ (narrow striped) of $\mathrm{NaCl}$ salt solution for 3 and 10 days. The values are means $\pm \mathrm{SD}$ of three replicates.

In P. maritimum, the effect of salt-stress on the concentration of protein in leaves and roots depended on both the $\mathrm{NaCl}$ concentration and the time of exposure to $\mathrm{NaCl}$ (Figure 4). After $3 \mathrm{~d}$ of treatment at $100 \mathrm{mM}$, the concentration of protein had significantly increased in roots and leaves, 3.3- and 1.6 times, respectively, with respect to the plants at $0 \mathrm{~d}$ before 
the start of treatments. After $10 \mathrm{~d}$, the protein concentration decreased in both roots and leaves to about $70 \%$ of the respective concentrations of the non-treated.

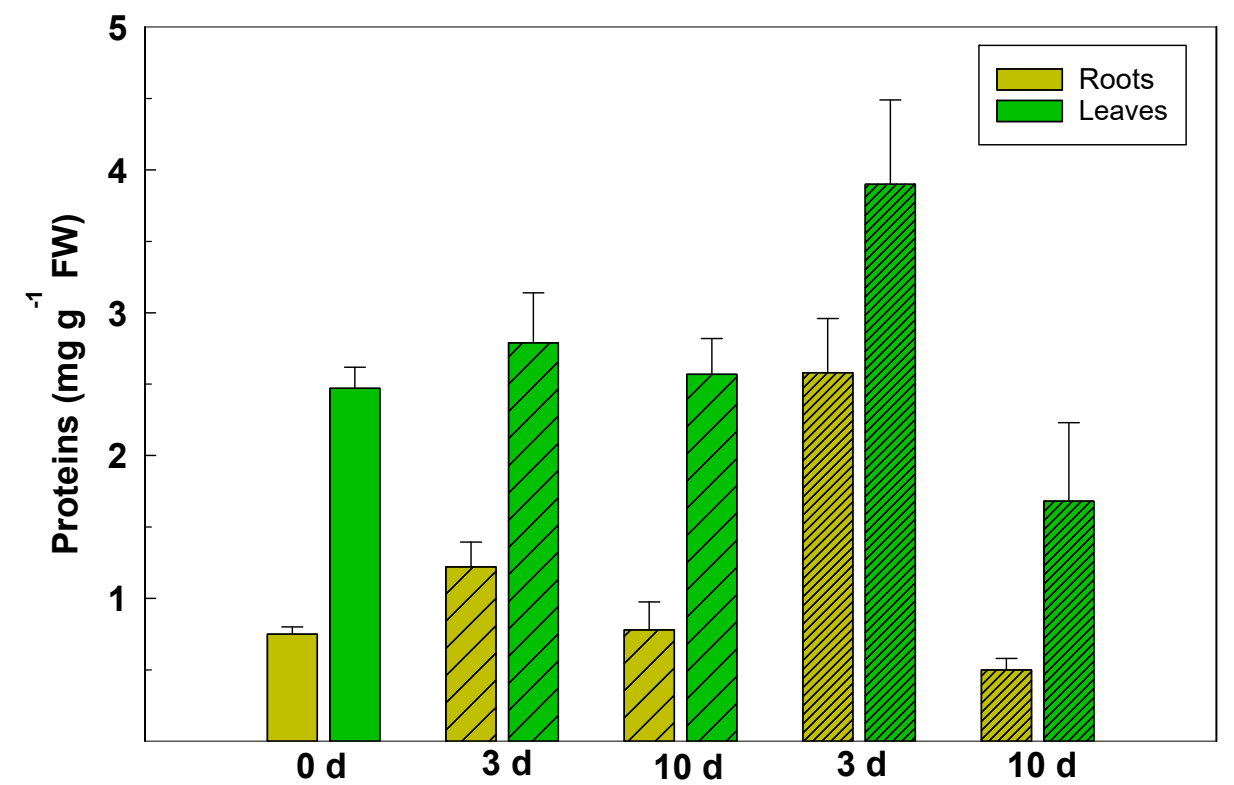

Figure 4. Total protein content ( $\left.\mathrm{mg} \mathrm{g}^{-1} \mathrm{FW}\right)$ in roots (light green) and leaves (brilliant green) tissue of $P$. maritimum plants irrigated with $50 \mathrm{mM}$ (wide striped) and $100 \mathrm{mM}$ (narrow striped) of $\mathrm{NaCl}$ salt solution for 3 and 10 days. The values are means \pm SD of three replicates.

\subsection{Concentrations of Minerals in Leaves and Roots}

The concentrations of $\mathrm{Na}, \mathrm{K}, \mathrm{Mg}, \mathrm{Ca}$ and $\mathrm{Fe}, \mathrm{Mn}, \mathrm{Zn}$, and $\mathrm{Cu}$ of the roots and leaves of P. maritimum are shown in Table 2. The Na concentration of roots and leaves differed significantly between the two salt treatments during the 10-day experimental period. At 3 and $10 \mathrm{~d}$ after salinity treatment was begun, the Na concentration continued to increase and was much higher in the roots than in leaves (Figure 5).

Table 2. Mineral elements ( $\mu \mathrm{mol} \mathrm{g}{ }^{-1} \mathrm{DW}$ ) in roots and leaves of $P$. maritimum irrigated with 50 and $100 \mathrm{mM}$ of $\mathrm{NaCl}$ salt solution at 3 and 10 days.

\begin{tabular}{|c|c|c|c|c|c|c|c|c|}
\hline & $\mathrm{Ca}$ & $\mathrm{Na}$ & $\mathbf{K}$ & Mg & $\mathrm{Cu}$ & $\mathrm{Zn}$ & $\mathrm{Fe}$ & Mn \\
\hline \multicolumn{9}{|l|}{$\begin{array}{c}\text { Roots } \\
\left(\mu \mathrm{mol} \mathrm{g}{ }^{-1} \mathrm{DW}\right)\end{array}$} \\
\hline Control & $50 \pm 4^{\mathrm{Bb}}$ & $240 \pm 15^{\mathrm{Dd}}$ & $400 \pm 25^{\mathrm{Aa}}$ & $165 \pm 11^{\mathrm{Aa}}$ & $0.95 \pm 0.06^{\mathrm{Cc}}$ & $2.50 \pm 0.2^{\mathrm{Cc}}$ & $25 \pm 3^{\mathrm{Cc}}$ & $6.5 \pm 0.5^{\mathrm{Bb}}$ \\
\hline $50 \mathrm{mM} 3 \mathrm{~d}$ & $45 \pm 5^{\mathrm{Bb}}$ & $380 \pm 10^{\mathrm{Ee}}$ & $350 \pm 28^{\mathrm{Ab}}$ & $150 \pm 11^{\mathrm{Aa}}$ & $0.90 \pm 0.04^{\mathrm{Cc}}$ & $2.80 \pm 0.3^{\mathrm{Cc}}$ & $22 \pm 2^{\mathrm{Cc}}$ & $7.1 \pm 0.6^{\mathrm{Bb}}$ \\
\hline $50 \mathrm{mM} 10 \mathrm{~d}$ & $45 \pm 6^{\mathrm{Bb}}$ & $510 \pm 18^{\mathrm{Ff}}$ & $300 \pm 32^{\mathrm{Ab}}$ & $135 \pm 11^{\mathrm{Ab}}$ & $0.85 \pm 0.05^{\mathrm{Cc}}$ & $3.00 \pm 0.2^{\mathrm{Cc}}$ & $20 \pm 2^{\mathrm{Cc}}$ & $7.6 \pm 0.7^{\mathrm{Bb}}$ \\
\hline $100 \mathrm{mM} 3 \mathrm{~d}$ & $40 \pm 6^{\mathrm{Bb}}$ & $524 \pm 19^{\mathrm{Gg}}$ & $280 \pm 29^{\mathrm{Ab}}$ & $130 \pm 7^{\mathrm{Ab}}$ & $0.88 \pm 0.04^{\mathrm{Cc}}$ & $3.10 \pm 0.2^{\mathrm{Cc}}$ & $21 \pm 2^{\mathrm{Cc}}$ & $7.5 \pm 0.8^{\mathrm{Bb}}$ \\
\hline $100 \mathrm{mM} 10 \mathrm{~d}$ & $29 \pm 4^{\mathrm{Cc}}$ & $890 \pm 28^{\mathrm{Hh}}$ & $170 \pm 21^{\mathrm{Cc}}$ & $110 \pm 8^{\mathrm{Ab}}$ & $0.65 \pm 0.06^{\mathrm{D}}$ & $3.50 \pm 0.3^{\mathrm{Cd}}$ & $17 \pm 1^{\mathrm{Cd}}$ & $8.5 \pm 0.7^{\mathrm{Bc}}$ \\
\hline \multicolumn{9}{|l|}{$\begin{array}{c}\text { Leaves } \\
\left(\mu \mathrm{mol} \mathrm{g}^{-1} \mathrm{DW}\right)\end{array}$} \\
\hline Control & $130 \pm 6^{\mathrm{Aa}}$ & $47 \pm 5^{\mathrm{Aa}}$ & $450 \pm 28^{\mathrm{Aa}}$ & $182 \pm 20^{\mathrm{Aa}}$ & $0.45 \pm 0.07^{\mathrm{Aa}}$ & $0.84 \pm 0.05^{\mathrm{Aa}}$ & $90 \pm 5^{\mathrm{Aa}}$ & $2.5 \pm 0.2^{\mathrm{Aa}}$ \\
\hline $50 \mathrm{mM} 3 \mathrm{~d}$ & $120 \pm 4^{\mathrm{Aa}}$ & $63 \pm 6^{\mathrm{Bb}}$ & $430 \pm 25^{\mathrm{Aa}}$ & $175 \pm 18^{\mathrm{Aa}}$ & $0.40 \pm 0.03^{\mathrm{Aa}}$ & $0.90 \pm 0.05^{\mathrm{Aa}}$ & $85 \pm 4^{\mathrm{Aa}}$ & $2.7 \pm 0.2^{\mathrm{Aa}}$ \\
\hline $50 \mathrm{mM} 10 \mathrm{~d}$ & $100 \pm 4^{\mathrm{Ab}}$ & $80 \pm 7^{\mathrm{Bb}}$ & $420 \pm 25^{\mathrm{Aa}}$ & $155 \pm 17^{\text {Aa }}$ & $0.35 \pm 0.04^{\mathrm{Ab}}$ & $0.96 \pm 0.05^{\mathrm{Aa}}$ & $80 \pm 7^{\text {Aa }}$ & $3.0 \pm 0.3^{\mathrm{Aa}}$ \\
\hline $100 \mathrm{mM} 3 \mathrm{~d}$ & $110 \pm 6^{\mathrm{Aa}}$ & $75 \pm 5^{\mathrm{Bb}}$ & $425 \pm 31^{\mathrm{Aa}}$ & $160 \pm 11^{\mathrm{Aa}}$ & $0.40 \pm 0.04^{\mathrm{Aa}}$ & $0.98 \pm 0.05^{\mathrm{Aa}}$ & $80 \pm 8^{\mathrm{Aa}}$ & $3.2 \pm 0.3^{\mathrm{Aa}}$ \\
\hline $100 \mathrm{mM} \mathrm{10d}$ & $90 \pm 4^{\mathrm{Ab}}$ & $110 \pm 6^{\mathrm{Cc}}$ & $400 \pm 35^{\mathrm{Aa}}$ & $130 \pm 11^{\mathrm{Ab}}$ & $0.30 \pm 0.04^{\mathrm{Ab}}$ & $1.30 \pm 0.05^{\mathrm{Bc}}$ & $70 \pm 7^{\mathrm{Ab}}$ & $3.5 \pm 0.3^{\mathrm{Ab}}$ \\
\hline
\end{tabular}

The values $\left(\mu \mathrm{mol} \mathrm{g}{ }^{-1} \mathrm{DW}\right)$ are means \pm SD of three replicates. The values marked by common letters are not statistically different at $p \leq 0.01$ (uppercase) or $p \leq 0.05$ (small letters) for values in the same column, according to Scheffè's test performed between control and plants with different treatment. 


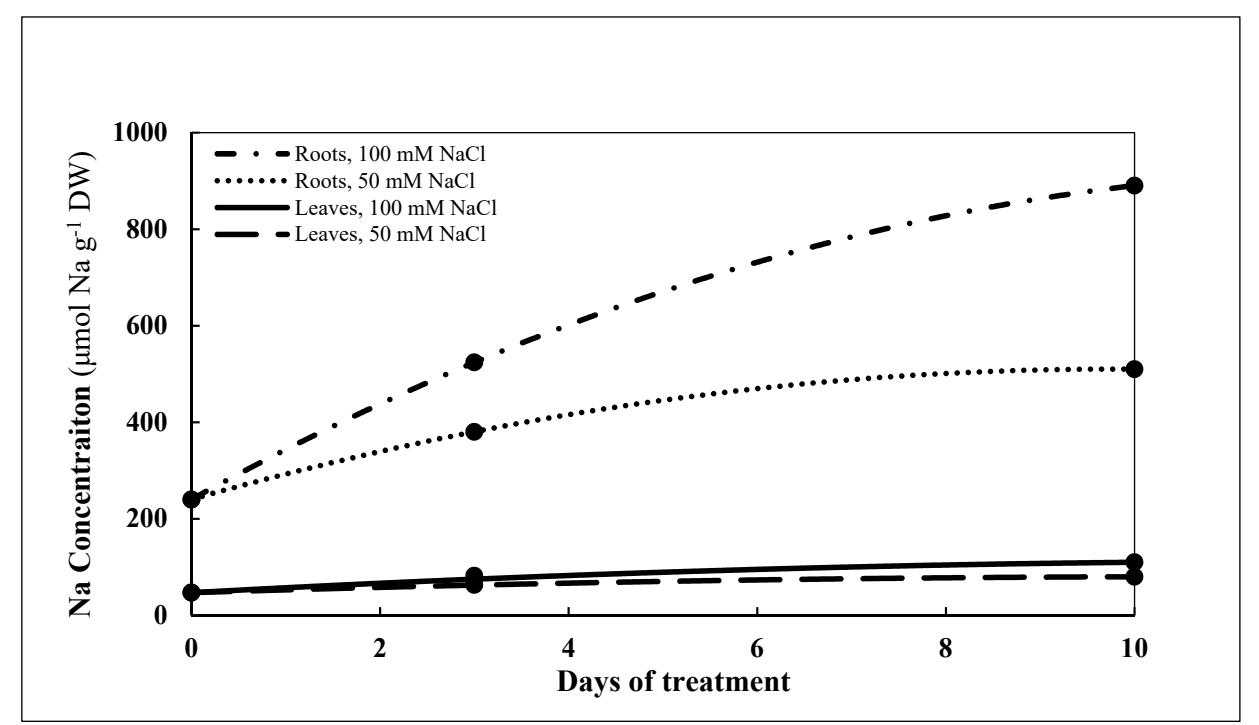

Figure 5. Estimates of concentration of $\mathrm{Na}\left(\mu \mathrm{mol} \mathrm{g}{ }^{-1} \mathrm{DW}\right)$ in roots and leaves of P. maritimum during 10 days of treatment with $50 \mathrm{mM} \mathrm{NaCl}$ or $100 \mathrm{mM} \mathrm{NaCl}$. Black dots represent the mean of three replicates.

The ratio of $\mathrm{Na}$ concentration of the leaves:roots (L:R) for the $50 \mathrm{mM} \mathrm{NaCl}$ treatment decreased from $0.19(0 \mathrm{~d})$ to $0.18(3 \mathrm{~d})$ to $0.16(10 \mathrm{~d})$, and the L:R ratio of Na content for the $100 \mathrm{mM} \mathrm{NaCl}$ treatment decreased from $0.20(0 \mathrm{~d})$ to $0.14(3 \mathrm{~d})$ to 0.12 (10 d) (Table S1).

In both untreated and treated plants, the concentrations of $\mathrm{Ca}, \mathrm{K}$, and $\mathrm{Mg}$ were higher in leaves than in the roots. L: $\mathrm{R}$ ratio of dry-weight concentration of $\mathrm{K}$, was 1.12 when the salinity treatments were begun at $0 \mathrm{~d}, 1.24$ at $3 \mathrm{~d}$, and 1.35 at $10 \mathrm{~d}$ with $50 \mathrm{mM} \mathrm{NaCl}$ treatment. The more stressful salinity treatment, $100 \mathrm{mM} \mathrm{NaCl}$, resulted in the $\mathrm{L}: \mathrm{R} \mathrm{K}$ ratio increasing from 1.12 at $0 \mathrm{~d}$ to 1.43 at $3 \mathrm{~d}$ and to 2.37 at $10 \mathrm{~d}$ (Table S1). The two salinity treatments caused decreases in concentrations of $\mathrm{K}, \mathrm{Mg}$, and $\mathrm{Ca}$ both in leaves and roots. In the leaves, the decrease in the dry-weight concentration of these macronutrients does not exceed $30 \%$ in the most drastic salinity conditions of $100 \mathrm{mM}$ at 10 days, i.e., 11, 27, and $30 \%$ for $\mathrm{K}, \mathrm{Mg}$, and $\mathrm{Ca}$, respectively. In the roots, however, there is a more marked decline: 35,40 , and $62 \%$ for $\mathrm{Mg}, \mathrm{Ca}$, and $\mathrm{K}$, respectively, while the dry-weight concentration does not exceed $25 \%$ at $50 \mathrm{mM} 10 \mathrm{~d}(11 \%, 18 \%$ and $25 \%$ for $\mathrm{Ca}, \mathrm{Mg}$, and $\mathrm{K}$, respectively).

There was a significant increase in the concentration of $\mathrm{Zn}$ and $\mathrm{Mn}$ in leaves and roots in response to stress due to the increased $\mathrm{NaCl}$ concentration in the soil and increased exposure time. Increases in dry-weight concentrations of $\mathrm{Mn}$ and $\mathrm{Zn}$ of the roots and leaves were gradual with increasing salt concentration, reaching $40-50 \%$ more than the control at 10 days when treated with $100 \mathrm{mM} \mathrm{NaCl}$. However, at 10 days, when treated with $100 \mathrm{mM} \mathrm{NaCl}$, concentrations of $\mathrm{Fe}$ and $\mathrm{Cu}$ had significantly decreased in leaves (20 and 30\%, respectively) and roots (33 and 31\%, respectively). Iron is notable in the present study, being the one element whose L:R ratio of dry-weight concentration was least for the control (3.6) at $0 \mathrm{~d}$, greater for the $50 \mathrm{mM} \mathrm{NaCl}$ treatment at $3 \mathrm{~d}$ and $10 \mathrm{~d}$ (3.9 and 4.1 , respectively) and greatest for the $100 \mathrm{mM} \mathrm{NaCl}$ treatment at $3 \mathrm{~d}$ and $10 \mathrm{~d}$ (3.8 and 4.3, respectively) (Table S1).

\subsection{Concentrations of Free Amino Acids, Proline, and Glycine Betaine}

An appreciable increase in the content of free amino acids ( $\left.\Sigma \mathrm{AA}, \mu \mathrm{mol} \mathrm{g}^{-1} \mathrm{FW}\right)$ was detected in roots and leaves of $P$. maritimum in response to salt stress of both 50 and $100 \mathrm{mM}$ $\mathrm{NaCl}$ (Table 3). Salt stress of $50 \mathrm{mM} \mathrm{NaCl}$ or $100 \mathrm{mM} \mathrm{NaCl}$ is associated with increases in the sum of concentrations of the 16 amino acids in the leaves from about $8.7 \mu \mathrm{mol} \mathrm{g}^{-1}$ FW in untreated plants to about $19.4 \mu \mathrm{mol} \mathrm{g}{ }^{-1} \mathrm{DW}$ with $50 \mathrm{mM} \mathrm{NaCl}$ treatment at $3 \mathrm{~d}$ and $37.5 \mu \mathrm{mol} \mathrm{g}{ }^{-1} \mathrm{DW}$ with $100 \mathrm{mM} \mathrm{NaCl}$ treatments at $10 \mathrm{~d}$. A significant accumulation of proline was measured (greater than 25-fold with respect to the control) in both roots 
and leaves with salt treatment of $100 \mathrm{mM}$ at $10 \mathrm{~d}$ (Table 3, Figure 6B). The concentration of proline in the leaves increased from $0.7 \mu \mathrm{mol} \mathrm{g}{ }^{-1} \mathrm{FW}$ at $0 \mathrm{~d}$ to $15 \mu \mathrm{mol} \mathrm{g}{ }^{-1} \mathrm{FW}$ with $50 \mathrm{mM}$ and $20 \mu \mathrm{mol} \mathrm{g}^{-1} \mathrm{FW}$ with $100 \mathrm{mM} \mathrm{NaCl}$ treatment after $10 \mathrm{~d}$. Concentrations of both glycine and serine were greater in the leaves, compared to the roots, where there was little change in concentration, when $P$. maritimum plants were exposed to $50 \mathrm{mM} \mathrm{NaCl}$ or $100 \mathrm{mM} \mathrm{NaCl}$ for $10 \mathrm{~d}$ (Table 3, Figure 6C,D). Concentrations of glutamic acid were higher in the leaves than in the roots during $10 \mathrm{~d}$ of exposure to $50 \mathrm{mM} \mathrm{NaCl}$ or $100 \mathrm{mM} \mathrm{NaCl}$, whereas the opposite occurred in the case of tryptophan (Table 3, Figure 6A,F).

Table 3. Free amino acid concentrations $\left(\mu \mathrm{mol} \mathrm{g}{ }^{-1} \mathrm{FW}\right)$ of roots and leaves of P. maritimum plants irrigated with 50 and $100 \mathrm{mM}$ of $\mathrm{NaCl}$ salt solution for 3 and 10 days.

\begin{tabular}{|c|c|c|c|c|c|}
\hline \multirow[b]{2}{*}{ Days } & \multirow{2}{*}{$\begin{array}{c}\text { Control } \\
0\end{array}$} & \multicolumn{2}{|c|}{$50 \mathrm{mM} \mathrm{NaCl}$} & \multicolumn{2}{|c|}{$100 \mathrm{mM} \mathrm{NaCl}$} \\
\hline & & 3 & 10 & 3 & 10 \\
\hline \multicolumn{6}{|l|}{$\begin{array}{c}\text { Roots } \\
\left(\mu \mathrm{mol} \mathrm{g}{ }^{-1} \mathrm{FW}\right)\end{array}$} \\
\hline Glycine & $0.30 \pm 0.03^{\mathrm{Aa}}$ & $0.35 \pm 0.03^{\mathrm{Aa}}$ & $0.45 \pm 0.03^{\mathrm{Ab}}$ & $0.35 \pm 0.02^{\mathrm{Aa}}$ & $0.50 \pm 0.05^{\mathrm{Ab}}$ \\
\hline Serine & $0.20 \pm 0.03^{\mathrm{Aa}}$ & $0.20 \pm 0.03^{\mathrm{Aa}}$ & $0.35 \pm 0.03^{\mathrm{Ab}}$ & $0.25 \pm 0.05^{\mathrm{Aa}}$ & $0.40 \pm 0.05^{\mathrm{Ab}}$ \\
\hline Aspartate & $1.00 \pm 0.30^{\mathrm{Aa}}$ & $1.50 \pm 0.30^{\mathrm{Aa}}$ & $1.50 \pm 0.40^{\mathrm{Aa}}$ & $1.40 \pm 0.40^{\mathrm{Aa}}$ & $1.70 \pm 0.40^{\mathrm{Aa}}$ \\
\hline Glutamate & $1.80 \pm 0.40^{\mathrm{Aa}}$ & $3.50 \pm 0.50^{\mathrm{Ab}}$ & $3.20 \pm 0.30^{\mathrm{Ab}}$ & $3.70 \pm 0.50^{\mathrm{Ab}}$ & $3.20 \pm 0.40^{\mathrm{Ab}}$ \\
\hline Asparagine & $0.25 \pm 0.06^{\mathrm{Aa}}$ & $0.50 \pm 0.07^{\mathrm{Ab}}$ & $0.50 \pm 0.06^{\mathrm{Ab}}$ & $0.50 \pm 0.07^{\mathrm{Ab}}$ & $0.70 \pm 0.07^{\mathrm{Ac}}$ \\
\hline Treonine & $0.04 \pm 0.005^{\mathrm{Aa}}$ & $0.08 \pm 0.01^{\mathrm{Ab}}$ & $0.07 \pm 0.01^{\mathrm{Ab}}$ & $0.10 \pm 0.02^{\mathrm{Ab}}$ & $0.10 \pm 0.02^{\mathrm{Ab}}$ \\
\hline Arginine & $0.40 \pm 0.08^{\mathrm{Aa}}$ & $0.60 \pm 0.10^{\mathrm{Ab}}$ & $0.60 \pm 0.07^{\mathrm{Ab}}$ & $0.50 \pm 0.08^{\mathrm{Aa}}$ & $0.60 \pm 0.10^{\mathrm{Ab}}$ \\
\hline Glutamine & $1.00 \pm 0.20^{\mathrm{Aa}}$ & $2.00 \pm 0.20^{\mathrm{Ab}}$ & $2.20 \pm 0.30^{\mathrm{Ab}}$ & $2.50 \pm 0.40^{\mathrm{Ab}}$ & $2.40 \pm 0.60^{\mathrm{Ab}}$ \\
\hline Alanine & $0.30 \pm 0.05^{\mathrm{Aa}}$ & $0.50 \pm 0.06^{\mathrm{Ab}}$ & $0.60 \pm 0.10^{\mathrm{Ab}}$ & $0.80 \pm 0.09^{\mathrm{Ab}}$ & $0.80 \pm 0.10^{\mathrm{Ab}}$ \\
\hline Tryptophan & $0.05 \pm 0.01^{\mathrm{Aa}}$ & $0.12 \pm 0.01^{\mathrm{Ab}}$ & $0.10 \pm 0.01^{\mathrm{Ab}}$ & $0.15 \pm 0.02^{\mathrm{Ab}}$ & $0.13 \pm 0.02^{\mathrm{Ab}}$ \\
\hline Valine & $0.04 \pm 0.01^{\mathrm{Aa}}$ & $0.07 \pm 0.01^{\mathrm{Ab}}$ & $0.08 \pm 0.01^{\mathrm{Ab}}$ & $0.10 \pm 0.02^{\mathrm{Ab}}$ & $0.10 \pm 0.02^{\mathrm{Ab}}$ \\
\hline Isoleucine & $0.02 \pm 0.004^{\mathrm{Aa}}$ & $0.05 \pm 0.01^{\mathrm{Ab}}$ & $0.07 \pm 0.01^{\mathrm{Ab}}$ & $0.07 \pm 0.01^{\mathrm{Ab}}$ & $0.08 \pm 0.01^{\mathrm{Ab}}$ \\
\hline Leucine & $0.04 \pm 0.01^{\mathrm{Aa}}$ & $0.08 \pm 0.01^{\mathrm{Ab}}$ & $0.08 \pm 0.01^{\mathrm{Ab}}$ & $0.10 \pm 0.02^{\mathrm{Ab}}$ & $0.09 \pm 0.02^{\mathrm{Ab}}$ \\
\hline Lysine & $0.05 \pm 0.01^{\mathrm{Aa}}$ & $0.09 \pm 0.03^{\mathrm{Ab}}$ & $0.08 \pm 0.02^{\mathrm{Ab}}$ & $0.10 \pm 0.02^{\mathrm{Ab}}$ & $0.10 \pm 0.02^{\mathrm{Ab}}$ \\
\hline Citrulline & $0.20 \pm 0.04^{\mathrm{Aa}}$ & $0.25 \pm 0.03^{\mathrm{Aa}}$ & $0.20 \pm 0.03^{\mathrm{Aa}}$ & $0.35 \pm 0.02^{\mathrm{Aa}}$ & $0.25 \pm 0.02^{\mathrm{Aa}}$ \\
\hline Proline & $0.30 \pm 0.05^{\mathrm{Aa}}$ & $2.60 \pm 0.40^{\mathrm{Bb}}$ & $6.00 \pm 1.00^{\mathrm{Cc}}$ & $4.00 \pm 0.70^{\mathrm{Bb}}$ & $8.00 \pm 0.60^{\mathrm{Cc}}$ \\
\hline$\Sigma \mathrm{AA}$ & $5.99 \pm 0.70^{\mathrm{Aa}}$ & $12.4 \pm 1.50^{\mathrm{Bb}}$ & $16.0 \pm 0.80^{\mathrm{Bc}}$ & $14.6 \pm 1.20^{\mathrm{Bc}}$ & $19.0 \pm 1.50^{\mathrm{Bd}}$ \\
\hline Glycine betaine & $1.00 \pm 0.17^{\mathrm{Aa}}$ & $1.00 \pm 0.02^{\mathrm{Aa}}$ & $4.00 \pm 0.7^{\mathrm{Bb}}$ & $1.30 \pm 0.30^{\mathrm{Aa}}$ & $6.00 \pm 0.70^{\mathrm{Bc}}$ \\
\hline \multicolumn{6}{|l|}{$\begin{array}{c}\text { Leaves } \\
\left(\mu \mathrm{mol} \mathrm{g}{ }^{-1} \mathrm{FW}\right)\end{array}$} \\
\hline Glycine & $0.60 \pm 0.06^{\mathrm{Aa}}$ & $0.90 \pm 0.08^{\mathrm{Bb}}$ & $1.80 \pm 0.40^{\mathrm{Cc}}$ & $1.60 \pm 0.30^{\mathrm{Cc}}$ & $2.50 \pm 0.30^{\mathrm{Dd}}$ \\
\hline Serine & $0.70 \pm 0.10^{\mathrm{Aa}}$ & $0.80 \pm 0.1 .0^{\mathrm{Aa}}$ & $1.60 \pm 0.30^{\mathrm{Bb}}$ & $1.20 \pm 0.20^{\mathrm{Bb}}$ & $2.00 \pm 0.30^{\mathrm{Cc}}$ \\
\hline Aspartate & $0.80 \pm 0.20^{\mathrm{Aa}}$ & $1.00 \pm 0.04^{\mathrm{Aa}}$ & $1.00 \pm 0.08^{\mathrm{Aa}}$ & $1.30 \pm 0.05^{\mathrm{Aa}}$ & $1.20 \pm 0.03^{\mathrm{Aa}}$ \\
\hline Glutamate & $2.40 \pm 0.30^{\mathrm{Aa}}$ & $4.00 \pm 0.70^{\mathrm{Bb}}$ & $4.00 \pm 1.00^{\mathrm{Bb}}$ & $4.50 \pm 0.20^{\mathrm{Bb}}$ & $4.00 \pm 0.90^{\mathrm{Bb}}$ \\
\hline Asparagine & $0.45 \pm 0.03^{\mathrm{Aa}}$ & $0.60 \pm 0.10^{\mathrm{Ab}}$ & $0.65 \pm 0.02^{\mathrm{Ab}}$ & $0.65 \pm 0.02^{\mathrm{Ab}}$ & $0.65 \pm 0.03^{\mathrm{Ab}}$ \\
\hline Treonine & $0.05 \pm 0.01^{\mathrm{Aa}}$ & $0.07 \pm 0.01^{\mathrm{Aa}}$ & $0.08 \pm 0.02^{\mathrm{Aa}}$ & $0.09 \pm 0.02^{\mathrm{Aa}}$ & $0.10 \pm 0.02^{\mathrm{Aa}}$ \\
\hline Arginine & $0.60 \pm 0.10^{\mathrm{Aa}}$ & $0.90 \pm 0.10^{\mathrm{Ab}}$ & $1.00 \pm 0.20^{\mathrm{Ab}}$ & $0.80 \pm 0.10^{\mathrm{Ab}}$ & $1.10 \pm 0.10^{\mathrm{Ab}}$ \\
\hline Glutamine & $1.50 \pm 0.25^{\mathrm{Aa}}$ & $3.00 \pm 0.70^{\mathrm{Bb}}$ & $2.80 \pm 0.20^{\mathrm{Bb}}$ & $3.20 \pm 0.33^{\mathrm{Bb}}$ & $3.00 \pm 0.20^{\mathrm{Bb}}$ \\
\hline Alanine & $0.50 \pm 0.08^{\mathrm{Aa}}$ & $0.70 \pm 0.08^{\mathrm{Aa}}$ & $0.90 \pm 0.10^{\mathrm{Aa}}$ & $0.90 \pm 0.20^{\mathrm{Aa}}$ & $1.20 \pm 0.30^{\mathrm{Aa}}$ \\
\hline Tryptophan & $0.05 \pm 0.01^{\mathrm{Aa}}$ & $0.07 \pm 0.02^{\mathrm{Aa}}$ & $0.09 \pm 0.01^{\mathrm{Aa}}$ & $0.09 \pm 0.01^{\mathrm{Aa}}$ & $0.10 \pm 0.02^{\mathrm{Aa}}$ \\
\hline Valine & $0.04 \pm 0.01^{\mathrm{Aa}}$ & $0.07 \pm 0.01^{\mathrm{Ab}}$ & $0.08 \pm 0.01^{\mathrm{Ab}}$ & $0.07 \pm 0.01^{\mathrm{Aa}}$ & $0.07 \pm 0.01^{\mathrm{Ab}}$ \\
\hline Isoleucine & $0.04 \pm 0.01^{\mathrm{Aa}}$ & $0.07 \pm 0.02^{\mathrm{Ab}}$ & $0.08 \pm 0.08^{\mathrm{Ab}}$ & $0.07 \pm 0.07^{\mathrm{Ab}}$ & $0.09 \pm 0.01^{\mathrm{Ab}}$ \\
\hline Leucine & $0.05 \pm 0.01^{\mathrm{Aa}}$ & $0.08 \pm 0.02^{\mathrm{Aa}}$ & $0.07 \pm 0.01^{\mathrm{Aa}}$ & $0.09 \pm 0.01^{\mathrm{Aa}}$ & $0.06 \pm 0.01^{\mathrm{Ab}}$ \\
\hline Lysine & $0.06 \pm 0.01^{\mathrm{Aa}}$ & $0.10 \pm 0.02^{\mathrm{Ab}}$ & $0.12 \pm 0.01^{\mathrm{Ab}}$ & $0.12 \pm 0.01^{\mathrm{Ab}}$ & $0.14 \pm 0.01^{\mathrm{Ab}}$ \\
\hline Citrulline & $0.20 \pm 0.05^{\mathrm{Aa}}$ & $0.35 \pm 0.03^{\mathrm{Ab}}$ & $0.45 \pm 0.05^{\mathrm{Ab}}$ & $0.30 \pm 0.05^{\mathrm{Ab}}$ & $0.40 \pm 0.06^{\mathrm{Ab}}$ \\
\hline Proline & $0.70 \pm 0.10^{\mathrm{Aa}}$ & $7.00 \pm 0.8^{\mathrm{Bb}}$ & $15.0 \pm 0.80^{\mathrm{Cc}}$ & $11.0 \pm 1.50^{\mathrm{Bd}}$ & $20.0 \pm 2.00^{\mathrm{De}}$ \\
\hline$\Sigma \mathrm{AA}$ & $8.70 \pm 0.70^{\mathrm{Aa}}$ & $19.4 \pm 1.40^{\mathrm{Bb}}$ & $29.7 \pm 1.90^{\mathrm{Cc}}$ & $25.7 \pm 1.60^{\mathrm{Cd}}$ & $37.5 \pm 1.70^{\mathrm{De}}$ \\
\hline Glycine betaine & $1.50 \pm 0.20^{\mathrm{Aa}}$ & $1.70 \pm 0.10^{\mathrm{Aa}}$ & $5.00 \pm 0.80^{\mathrm{Ab}}$ & $1.60 \pm 0.05^{\mathrm{Aa}}$ & $6.50 \pm 1.00^{\mathrm{Ab}}$ \\
\hline
\end{tabular}

The values are means \pm SD of three replicates. The values marked by common letters are not statistically different at $p \leq 0.01$. (uppercase) or $p \leq 0.05$ (small letters) for values in the same row, according to Scheffè's test performed between control and plants with different treatment. 


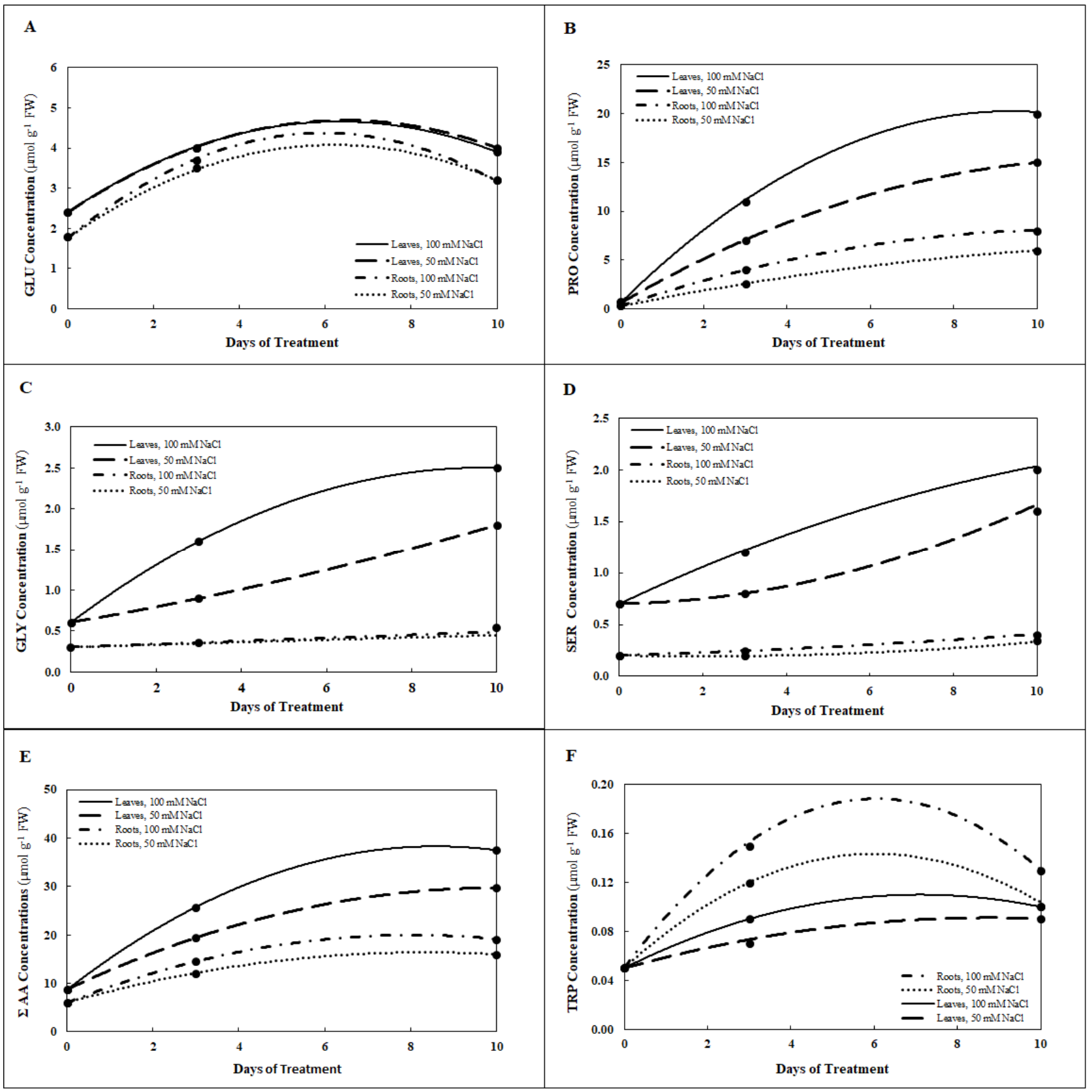

Figure 6. Estimates of concentrations ( $\mu \mathrm{mol} \mathrm{g}^{-1} \mathrm{FW}$ ) of glutamic acid (GLU, A), proline (PRO, B), glycine (GLY, C), serine (SER, D), the sum of amino acids in Table 3 ( $\mathrm{AAA}, \mathbf{E})$, and tryptophan (TRP, F) in roots and leaves of P. maritimum during 10 days of treatment with $50 \mathrm{mM} \mathrm{NaCl}$ or $100 \mathrm{mM} \mathrm{NaCl}$. Black dots represent the mean of three replicates.

The amino acid derivative glycine betaine (trimethylglycine) increased in roots as well as in leaves, reaching maximum concentrations in both organs after salt treatment for $10 \mathrm{~d}$ (Table 3). The concentration of glycine betaine in the leaves increased from $1.5 \mu \mathrm{mol} \mathrm{g}^{-1}$ FW at $0 \mathrm{~d}$ to $5.0 \mu \mathrm{mol} \mathrm{g}{ }^{-1} \mathrm{FW}$ and to $6.5 \mu \mathrm{mol} \mathrm{g}{ }^{-1} \mathrm{FW}$ at $10 \mathrm{ds}$ with 50 and $100 \mathrm{mM} \mathrm{NaCl}$ treatments, respectively (Figure 7). Concentrations of the amino acids determined and of glycine betaine also increased in the roots in response to salinity. 


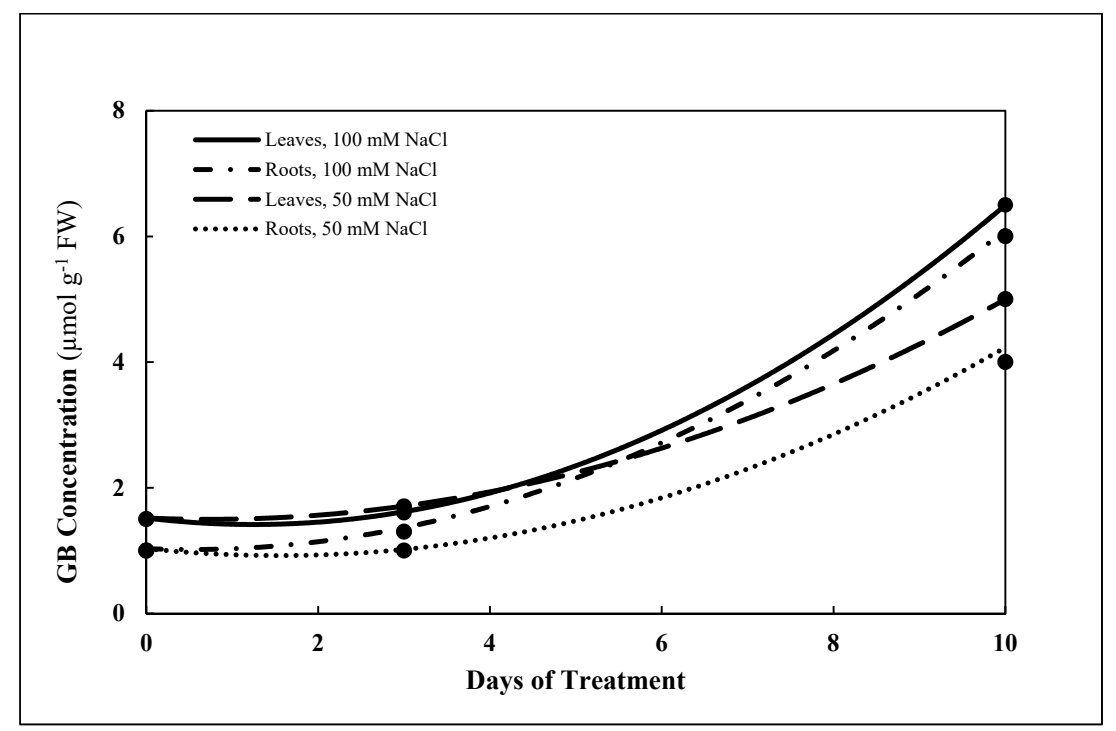

Figure 7. Estimates of concentration $\left(\mu \mathrm{mol} \mathrm{g}{ }^{-1} \mathrm{FW}\right)$ of glycine betaine (GB) in roots and leaves of P. maritimum during 10 days of treatment with $50 \mathrm{mM} \mathrm{NaCl}$ or $100 \mathrm{mM} \mathrm{NaCl}$. Black dots represent the mean of three replicates.

\subsection{Principal Component Analysis}

The first two principal components (PCs) explain 63\% of total variance (Figure 8). The plot clearly shows a separation associated mostly with type of plant tissue (leaves on the right and roots on the left of PC1), and a secondary split is seen on PC2, associated with salinity and days of treatment. Despite the overall higher activities in leaves compared to roots (explained by the split on PC1), the differences on PC2 were comparable between leaf and root tissues. In detail, the control at $0 \mathrm{~d}$ and $50 \mathrm{mM} \mathrm{NaCl}$ treatment after $3 \mathrm{~d}$ showed higher GSSG, GSH, and OAS-TL activities. The $100 \mathrm{mM} \mathrm{NaCl}$ treatment at 3 and $10 \mathrm{~d}$ and the $50 \mathrm{mM} \mathrm{NaCl}$ treatment after $3 \mathrm{~d}$ all exhibited higher concentration of Gly, proteins, Glu, and $\mathrm{NADP}^{+}$. Noticeably, the NADPH concentration peaked at $3 \mathrm{~d}$ in the $100 \mathrm{mM}$ treatment both in roots and leaves.

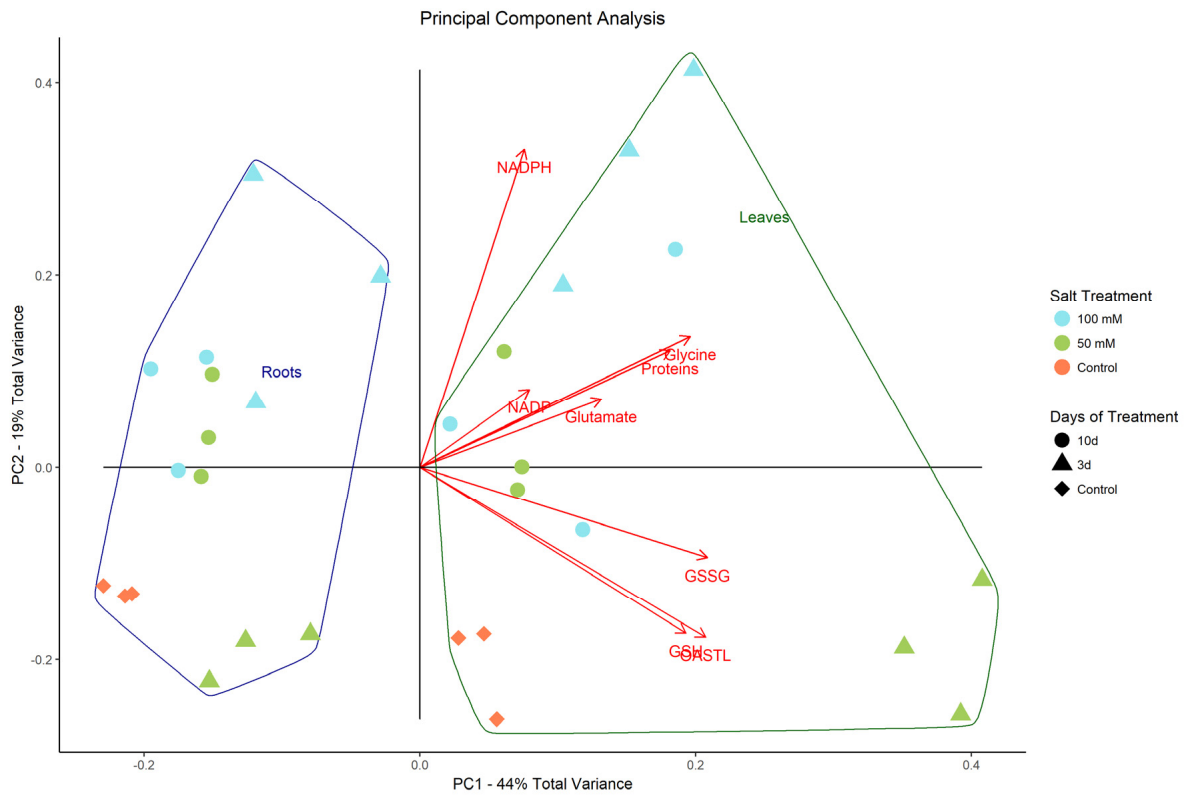

Figure 8. Principal Component Analysis, or PCA (PC1 and PC2: 63\%): PCA biplot displaying distribution of treatments grouped according to different salt concentration (50 and $100 \mathrm{mM}$ ) and days of exposure ( 3 and 10 days). 


\section{Discussion}

In general, plants respond to salinity with an increase in abscisic acid, a biomolecular mediator in plant responses to salt stress, and with a decrease in stomatal aperture to maintain internal water content. As a result, $\mathrm{CO}_{2}$ fixation by the Calvin cycle is limited, with a consequent reduction of $\mathrm{NADP}^{+}$stromal concentration. Under the mild stress applied, no obvious physiological alterations such as growth inhibition or dehydration symptoms were observed, but our results show a metabolic response, namely a decrease of the $\mathrm{NADP}^{+} / \mathrm{NADPH}$ redox ratio in leaves of salt stressed P. maritimum plants. These results are consistent with the ability of the photosynthetic cell, under conditions of mild stress, to respond to a significant decrease in the $\mathrm{NADP}^{+} / \mathrm{NADPH}$ ratio, indicating an altered synergy in the redox balance between the light and dark phases of photosynthesis, triggering the pseudo-cyclic electron transport chain. In fact, a decrease in the $\mathrm{NADP}^{+} / \mathrm{NADPH}$ redox ratio in leaves of salt-stressed plants, most likely due to a limitation of $\mathrm{CO}_{2}$ fixation, could increase the formation of reactive oxygen species (ROS) and the activity of biochemical processes involved in oxidative stress detoxification. In plants, adverse environmental conditions such as drought, high and low temperatures, or salinity promote the overproduction of ROS resulting in disruption of the intracellular redox equilibrium [22]. To counteract the harmful effects of ROS, plants maintain cellular redox homeostasis by utilizing many compounds that are antioxidative electron donors. Antioxidants are molecules with a low molecular mass capable of inhibiting or quenching free radical reactions, thereby preventing damage to cellular molecules.

Among antioxidants, the tripeptide glutathione plays a key role in responding to environmental stress such as salinity and is a major factor responsible for salt tolerance of the halophyte [23]. In addition, under environmental stress, the reduced and oxidized forms of glutathione (GSH and GSSG) may also have role in regulating stress-related marker genes at the transcriptional level [23]. The total glutathione concentration increased in P. maritimum plants treated with salt. The reduced form of glutathione, GSH, may have protected the plants from salt stress, since the concentration of GSH increased more than three-fold in the leaves of plants under moderate stress of $50 \mathrm{mM} \mathrm{NaCl}$ for $3 \mathrm{~d}$. At the same time that GSH increased in the leaves of these plants, the concentration of GSSG increased in the roots. As the oxidized form GSSG tended to increase in the roots under moderate salt stress, the reduced form GSH in the roots tended to decrease as time progressed during the experiment.

In the treated plants, the increase in total glutathione was more evident in the roots with a greater proportion in the oxidized fraction, confirming a more energetic response to stress in these organs, with respect to the leaves. Nicotinamide adenine dinucleotide phosphate is the oxidative-reductive cofactor of the enzyme glutathione reductase. This enzyme, in fact, regenerates GSH from GSSG through the electrons transferred from the reducing agent, NADPH. This would explain the increase of GSH in the leaves that could also be interpreted as a drain of reduction equivalents to avoid the trigger of a pseudocyclic electronic transport, such as commonly occurs in osmotic stress conditions. The maintenance of a high GSH to GSSG ratio in the leaves (Figure S1) through a NADPHdependent plastid GSSG reductase [24-26] could be a factor that improves the salt tolerance in P. maritimum plants by diminishing oxidative stress in these organs. In fact, the loss of productivity in all plants under salt stress is generally associated to the overproduction of ROS and the change of redox state of the cell [12,23-25]. Regardless of level of sodium chloride (50 or $100 \mathrm{mM}$ ), the concentration of GSSG was higher than that of GSH in the leaves and in the roots, suggesting that (1) reduced glutathione (GSH) served as a prominent, protective electron donor in response to oxidative stress in both organs and (2) in P. maritimum, glutathione appears to be a key factor contributing to salt-tolerance. Moreover, the concentration of GSSG was higher with exposure to $100 \mathrm{mM} \mathrm{NaCl}$ than with exposure to $50 \mathrm{mM} \mathrm{NaCl}$ in both leaves and roots, indicating a more robust presence of glutathione in the leaves where photosynthesis requires protection from ROS to function. 
In plants subjected to mild salt stress ( $50 \mathrm{mM} \mathrm{NaCl}$ for $3 \mathrm{~d}$ ), the increase of glutathione content in the leaves was supported by enhancement of OAS-TL enzymes, as indicated by Spearman positive correlation (Figure S2). In plants, OAS-TL carries out the cysteine biosynthesis from O-acetyl-L-serine $[27,28]$. Among proteins up-regulated by salt-stress, the OAS-TLs enzyme seems to have an important role. In leaves, after $3 \mathrm{~d}$ of $50 \mathrm{mM} \mathrm{NaCl}$ treatment, the high activity of OAS-TL corresponds to a relatively high concentration of GSH. In roots, the salt treatment slightly increased the activity of OAS-TL at the concentration of $50 \mathrm{mM} \mathrm{NaCl}$ and did not affect the activity of OAS-TL at the concentration of $100 \mathrm{mM} \mathrm{NaCl}$. Moreover, OAS-TL gene expression in P. maritimum in response to mild salt stress [29] has been reported as being highest in leaves, followed by lesser responses in the roots and bulbs. Unlike other plants where higher amounts of OAS-TL transcripts occur in the roots under stress [19], OAS-TL mRNA expression in roots of moderately salt-stressed P. maritimum remained almost unchanged [29].

The OAS-TL mRNA expression and activity enhancement in leaves might be explained by increased demand for cysteine needed for glutathione synthesis. The high demand for cysteine during salt stress is also in agreement with the role of sulfur-containing compounds that function as osmolytes or antioxidants [30]. This means that the synthesis of cysteine and of thiol compounds such as glutathione in P. maritimum plants represents an essential early reaction mechanism following the exposure of the plants to salinity, decreasing gradually with time.

Metabolism of total protein in P. maritimum was profoundly affected by salt. The significant change in protein contents in both the roots and the leaves points to an imbalance between anabolic and catabolic processes. Such an imbalance in response to saline stress could occur either from up-regulation or down-regulation of the synthesis of proteins [31]. The higher concentrations of protein in the salt-stressed plants, compared to the untreated plants, may possibly be an initial defense against osmotic stress, and after $10 \mathrm{~d}$, the decreased concentrations of protein in the fresh tissue may be a result of disintegration of stress-damaged proteins. Furthermore, the concentrations of $\mathrm{NAD}^{+}$and NADH in the roots and leaves provide a measure of the oxidative metabolism of carbon bonds which are the main source of reduction equivalents. The energy required by the cell to ensure a homeostatic reaction mainly through membrane ATPase activity and synthesis of osmolytes and free amino acids in the roots can only be provided by the oxidation of glucose. This cellular energy flow through glycolysis and the Krebs cycle increases ATP levels and the $\mathrm{NADH} / \mathrm{NAD}^{+}$ratio.

According to Morant-Avice et al. [32], proteins are very susceptible to severe salttoxicity because their synthesis is dependent on physiological potassium $\left(\mathrm{K}^{+}\right)$and because absorption of $\mathrm{K}^{+}$is inhibited by excess of sodium $\left(\mathrm{Na}^{+}\right)$and chloride $\left(\mathrm{Cl}^{-}\right)$[33]. Saline stress also causes a physiological imbalance between $\mathrm{Na}^{+}$and $\mathrm{K}^{+}$, an essential macronutrient that is crucial for protein synthesis [33,34].

Our data clearly show that P. maritimum is able to protect its photosynthetic organs from toxic levels of $\mathrm{Na}$ by, at least partially, accumulating relatively large concentrations of $\mathrm{Na}$ in the roots. This is a general feature of salt-tolerant monocotyledonous, which largely base their mechanisms of salt tolerance on blocking the transport of toxic ions to the aboveground plant organs [5]. During the 10-day experimental period with treatments of $50 \mathrm{mM}$ or $100 \mathrm{mM} \mathrm{NaCl}$, Na accumulated in the roots, i.e., $270 \mu \mathrm{mol} \mathrm{Na}^{-1} \mathrm{DW}$ and $650 \mu \mathrm{mol} \mathrm{Na} \mathrm{g}{ }^{-1} \mathrm{DW}$, respectively, more than the concentration of Na before the treatments were begun. Accumulation of $\mathrm{Na}$ in the leaves gradually appeared, being limited to $63 \mu \mathrm{mol}$ $\mathrm{Na} \mathrm{g}^{-1} \mathrm{DW}$ more than untreated plants after $10 \mathrm{~d}$ of treatment with $100 \mathrm{mM} \mathrm{NaCl}$. These results indicate that $P$. maritimum accumulated and stored large quantities of $\mathrm{Na}$ in the roots, probably in the vacuoles of parenchymal cells [35] thereby inhibiting Na transfer to the leaves. In plants sampled before treatment was begun and during treatment at 3 and $10 \mathrm{~d}, \mathrm{Ca}, \mathrm{K}$, and $\mathrm{Mg}$ contents were higher in leaves than in the roots, indicating that these three elements, after absorption by the roots, were being translocated to the leaves where they could contribute to photosynthetic metabolism and other metabolic processes. Unlike 
other plants where the decrease in $\mathrm{Ca}$ and $\mathrm{Mg}$ concentrations was significant and started at lower salinity level ( $25 \mathrm{mM} \mathrm{NaCl})$ [36], in P. maritimum, $\mathrm{Ca}$ and $\mathrm{Mg}$ concentrations in both roots and leaves remain relatively unchanged during treatment with a $25 \%$ drop only after $10 \mathrm{~d}$ at $100 \mathrm{mM} \mathrm{NaCl}$; this decrease of $25 \%$ was probably not sufficient to generate physiological alterations to the plant.

The cations $\mathrm{K}^{+}, \mathrm{Na}^{+}, \mathrm{NH}_{4}{ }^{+}$, and $\mathrm{H}^{+}$directly and indirectly depress $\mathrm{Ca}^{2+}$ and $\mathrm{Mg}^{2+}$ uptake and distribution [37] probably acting as antagonists to $\mathrm{Ca}^{2+}$ and $\mathrm{Mg}^{2+}$ uptake. Moreover, $\mathrm{K}^{+}$plays essential roles in enzyme activation and plasma membrane protein synthesis. Though, on the whole, $\mathrm{Ca}^{2+}$ and $\mathrm{Mg}^{2+}$ were the less affected cations, compared to the monovalent cations, a significant reduction in calcium could make the plasma membrane more permeable, resulting in less well-controlled influx and efflux. Salinity can increase the incidence of calcium-related physiological disorders either by competition between $\mathrm{Na}^{+}$and $\mathrm{Ca}^{2+}$ during uptake, or by decreasing the soil water potential and thus root pressure [38]. Although numerous studies have addressed the effect of $\mathrm{Mg}$ deficiency on biomass and photosynthetic $\mathrm{CO}_{2}$ assimilation, in P. maritimum the $\mathrm{Mg}$ concentrations remain substantially unchanged during treatment and there are no effects of $\mathrm{Mg}$ deficiency. In P. maritimum, the L:R ratio of total dry-weight concentration of $\mathrm{K}$ increased in plants salt-stressed with $50 \mathrm{mM} \mathrm{NaCl}$ at 3 and $10 \mathrm{~d}$, respectively. The more stressful salinity treatment, $100 \mathrm{mM} \mathrm{NaCl}$ for $10 \mathrm{~d}$, resulted in a strong $\mathrm{K} \mathrm{L}: \mathrm{R}$ ratio increase.

The increase in the accumulation of ions like $\mathrm{Na}^{+}$and $\mathrm{Cl}^{-}$caused toxicity in the roots of P. maritimum plants, since high concentrations of $\mathrm{Na}^{+}$plus $\mathrm{Cl}^{-}$in soil have been shown to decrease the uptake and assimilation of $\mathrm{K}^{+}$and $\mathrm{Ca}^{2+}$, resulting in a reduction of photosynthesis, stomatal conductance, and chlorophyll content like in other plants $[39,40]$. The uptake and assimilation of micronutrients under salt stress depends upon genotype and salinity level [33]. The availability of micronutrients under salt stress is affected by many factors such as micronutrient solubility, and the $\mathrm{pH}$ and redox potential of the soil solution $[38,41]$.

There was a significant increase in the concentration of $\mathrm{Zn}$ and $\mathrm{Mn}$ in leaves and roots in response to stress due to increased $\mathrm{NaCl}$ concentration and exposure time. The increases in dry-weight concentrations of $\mathrm{Mn}$ and $\mathrm{Zn}$ in the roots and leaves were gradual with increasing salt concentration. At $10 \mathrm{~d}$, when plants were treated with $100 \mathrm{mM} \mathrm{NaCl}$, concentrations of $\mathrm{Fe}$ and $\mathrm{Cu}$ had significantly decreased in leaves. Iron is notable in the present study, being the one element whose L:R ratio of dry-weight concentration increased with $\mathrm{NaCl}$ concentrations and duration of treatment. However, the foliar concentration of Fe at 10 days with $100 \mathrm{mM} \mathrm{NaCl}$ treatment, the most stressful combination of duration and concentration, indicates that Fe could still be sufficient to guarantee metabolic functions such as chlorophyll synthesis, photosynthesis, respiration, and normal functioning of many enzymes of which Fe is a cofactor [42]. Similarly, Mn also plays an important role as an activator of various enzymes such as decarboxylase, dehydrogenase, superoxidase, and phosphatase, as well as functioning as a constituent of photosystem II protein in photosynthesis. Finally, the micronutrients $\mathrm{Fe}, \mathrm{Mn}$, and $\mathrm{Zn}$ improve plant tolerance against salt stress by activating the synthesis of proline, an osmoprotectant that helps to tolerate the effect of salts [43].

Total amino acid content in response to salt treatment has been reported to increase in several plant species [44]. An appreciable increase in the concentrations of free amino acids was detected in roots and leaves of P. maritimum in response to mild salt stress at both 50 and $100 \mathrm{mM} \mathrm{NaCl}$. Glutathione is a tripeptide formed by three amino acids, Cys, Gly, and Glu. In both roots and leaves of plants treated with $100 \mathrm{mM} \mathrm{NaCl}$, the concentrations of Gly were greater, with respect to untreated plants. Also, the concentrations of Glu, Gln, and Ala were higher in roots and leaves of plants salt stressed, compared to those untreated, suggesting a general unbalancing of nitrogen assimilation [35].

Concentrations of tryptophan were higher in the roots than in the leaves during the entire $10 \mathrm{~d}$ of exposure to $50 \mathrm{mM} \mathrm{NaCl}$ or $100 \mathrm{mM} \mathrm{NaCl}$. In plants, tryptophan is the primary precursor of the predominant endogenous auxin (indole-3-acetic acid). One of 
the hormones involved in plants' response to salt stress response is auxin. Ribba et al. [45] reported that increased auxin levels can lead to a reduction in uptake of toxic ions by plants under salt stress. Therefore, our data may indicate that the relatively high concentrations of tryptophan in the roots of P. maritimum in the roots, compared to the leaves, are a part of complex tolerance mechanisms protecting P. maritimum from adverse effects of moderate salt stress.

These findings, in addition to the confirmation of the important role of the pool of free amino acids in osmoregulation, are consistent with the reports of large increases of protein content in the early stages of salt stress.

The increase in free amino acids was mainly due to the intracellular increase of proline in both roots and leaves that was most pronounced with salt treatment of $100 \mathrm{mM}$ for $10 \mathrm{~d}$. Proline plays important protective roles in the acclimation to salinity stress by osmotic adjustments and protecting plants' subcellular structures [46]. Besides functioning as a compatible solute [44], proline, as it accumulates during salt stress, may be involved as signal-inducing for dehydrin synthesis in roots and stems or may be associated with stress-responsive genes [47]. In addition to proline, glycine betaine, another compatible solute having an important role in tolerance to osmotic stress, increased in roots as well as in leaves, but only after a prolonged salt treatment for $10 \mathrm{~d}$. All plant cells, when kept in a low water potential environment, increase the internal concentration of osmolytes. To avoid shrinkage and/or swelling of intracellular organelles, equivalent concentrations of such compounds must be kept in the intracellular compartments [35]. The similar increase of osmolarity, as a result of storage of soluble organic nitrogen compounds (the amino acids proline and glutamic acid and the amino acid derivative glycine betaine) in the leaves and roots of salt-stressed P. maritimum, suggests that different osmo-regulatory responses may also depend on different osmotic stresses in different plant organs and organelles. These findings, in addition to the confirmation of the important simultaneous roles of the amino acids in osmoregulation, are consistent with the reported high increase of protein content in P. maritimum in the early stages of salt stress. On the other hand, after $10 \mathrm{~d}$ with relatively severe stress conditions $(100 \mathrm{mM})$, the increase in free amino acids in both roots and leaves (56 and 66\%, respectively), could be partially attributed to catabolic processes such as protein hydrolysis or proline conversion, and partially to anabolic processes such as their biosynthesis.

The simultaneous increases of the concentrations of the intracellular free amino acids, especially of proline, and their osmotic properties could result in further, simultaneous metabolic interactions in the defense of osmotic stress. For example, the synthesis of plastid proline [48] occurs through a reduction process of Glu, and reduction of Glu involves an inevitable drainage of reduction equivalents from the plastid stroma, reducing the damage of an osmotic stress, such as the triggering of a pseudo-cyclic electron transport and ROS generation. Moreover, the simultaneous increase in the concentration of intracellular Gly and Ser (400 and 300\% more than untreated plants) in the leaves of plants irrigated with $100 \mathrm{mM} \mathrm{NaCl}$ for $10 \mathrm{~d}$ expresses an ongoing photorespiratory activity. As is well known, the amino acids indicating a photorespiratory activity are Gly, which is a constituent of glutathione, and Ser, which is the precursor of O-Acetylserine, substrate of OAS-TL enzyme. $\mathrm{O}$-acetylserine is biosynthesized by acetylation of Ser by the enzyme serine acetyltransferase [49]. The enzyme $O$-acetylserine (thiol)-lyase, using sulfide sources, converts this ester into cysteine, releasing acetate. From a careful reading of the experimental data, it is possible to rationally conclude that photorespiration can biochemically support the metabolism of sulfur and the synthesis of glutathione, whose reduction is catalyzed by NADPH-dependent chloroplastic glutathione reductase enzyme.

The present investigation provides glimpses of many elemental and molecular components that act together simultaneously in the complex metabolic and physiological system of the P. maritimum. The results of the present investigation demonstrate many aspects of metabolism that $P$. maritimum has evolved to defend itself against the metabolic instability that can result from increased concentration of $\mathrm{NaCl}$ in the root zone. 


\section{Materials and Methods}

\subsection{Plant Growth and Treatment}

P. maritimum plants were collected from dunes in Cuma (near Naples, Italy) and were cultivated in pots with their original, sandy substrate. The plants were supplied every two days (d) with $200 \mathrm{~mL}$ of Hoagland solution [50]. After $7 \mathrm{~d}$ of pre-treatment with Hoagland solution, the plants were divided into 3 groups: (1) Control; (2) Hoagland solution plus $50 \mathrm{mM} \mathrm{NaCl}$; and (3) Hoagland solution plus $100 \mathrm{mM} \mathrm{NaCl}$. Three replicate control plants were harvested before treatments were applied. At 3 and $10 \mathrm{~d}$ after treatments were begun, three replicate plants were harvested for each of the two salinity treatments. Leaves and roots were harvested from the bulb of each plant. These two organs excised from plants were washed with deionized water, fresh weight was determined, and then samples of the organs were blot-dried and frozen in liquid nitrogen before being used for enzyme assays and biochemical measurements. Other samples of the roots and leaves were air-dried in a heater with constant heat control at $40{ }^{\circ} \mathrm{C}$ to constant dry weight for mineral analysis.

\subsection{Analyses of Amino Acids, Proline, Glycine Betaine, Pyridine Nucleotides}

Aliquots of fine, powdered samples of leaves (200 mg FW) and roots (350 FW) from five plants per treatment were used for chemical determination of amino acids and pyridine nucleotides. The samples were separately suspended in $2 \mathrm{~mL}$ of ethanol/water $(80 / 20 \mathrm{v} / \mathrm{v})$. After $30 \mathrm{~min}$, the suspension was collected and centrifuged. The supernatant was used to determine the concentration of amino acids and nucleotides on a fresh-weight basis. The primary amino acids were determined by autosampler-assisted pre-column derivatization by o-phthaldialdehyde (OPA), separation by C 18 reverse-phase high-performance liquid chromatography (HPLC) and fluorescence detection (excitation at $340 \mathrm{~nm}$ and emission at $450 \mathrm{~nm}$ ) [35]. Proline was determined by HPLC as fluorescent 9-fluorenylmethoxycarbonyl derivative (P-FMOC-carbamate) on sample extracts that were previously derivatized by OPA reagent to remove the primary amino acids and fluorometrically detected using excitation at $254 \mathrm{~nm}$ and emission at $315 \mathrm{~nm}$ [35]. The nucleotides were determined by reverse-phase high-performance liquid chromatography (HPLC). Column: SUPELCOSIL LC-18-T ( $3 \mu \mathrm{m}$ particles) with guard column. Mobil phase: $\mathrm{A}=0.1 \mathrm{M} \mathrm{KH}_{2} \mathrm{PO}_{4}$ plus $4 \mathrm{mM}$ tetrabutylammonium hydrogen sulfate $\mathrm{pH} 6 ; \mathrm{B}=\mathrm{A}$ : methanol, 70:30, $\mathrm{pH} 7,2$. Flow rate 1,5 mL/ min Det: $254 \mathrm{~nm}$. Gradient program: Time (min) 0\% B 0; 2.5-0; 5-30; 10-60; 13-0; 17-0; 18-100 [51]. The chemical analyses were repeated three times. In the analysis of each compound, the measurements were repeated using at least three different samples for each treatment. The results are given as the mean $\pm \mathrm{SD}(\mathrm{n}=3)$ of replicates within each experiment.

\subsection{Glutathione Determination}

Fresh leaves and roots ( $1 \mathrm{~g})$ from five plants of $P$. maritimum were crushed in mortars with liquid nitrogen, and $2 \mathrm{~mL}$ of $5 \%$ sulfosalicylic acid were added to the powdered tissue. The homogenates were centrifuged at $12000 \times g$ for $15 \mathrm{~min}$ at $4{ }^{\circ} \mathrm{C}$. Reduced, disulfhydryl glutathione (GSH) and oxidized glutathione disulfide (GSSG) were determined according to Carfagna et al. [17]. The extract $(100 \mu \mathrm{L})$ was added to $600 \mu \mathrm{L}$ of reaction buffer $(0.1-\mathrm{M}$ Na-phosphate, pH 7.00, and 1-mM of ethylenediaminetetraacetic acid (EDTA), $40 \mu \mathrm{L}$ of $0.4 \%$ 5,50 -dithiobis-(2-nitrobenzoic acid) (DTNB) (5,50 -dithiobis-2-nitrobenzoic acid), and $400 \mu \mathrm{L}$ of distilled water. The GSH content was determined at $412 \mathrm{~nm}$ after $5 \mathrm{~min}$. Then, $50 \mu \mathrm{L}$ of $0.4 \%$ reduced nicotinamide adenine dinucleotide phosphate (NADPH) and $1 \mu \mathrm{L}$ of glutathione reductase (GR) (0.5 U) were added to the reaction mixture, and the content of total glutathione (GSH plus GSSG) was determined at $412 \mathrm{~nm}$ after $30 \mathrm{~min}$ of incubation at room temperature. Amounts of GSH and GSSG were expressed in $\mu \mathrm{mol} \mathrm{g}^{-1} \mathrm{FW}$.

\subsection{O-acetyl-l-serine(thiol)lyase (OAS-TL) Enzymatic Activities and Protein Determination}

One gram of fresh leaves and roots of $P$. maritimum was crushed by mortar in liquid nitrogen, and to the powder, $2 \mathrm{~mL}$ of lysis buffer (50 mM phosphate-buffer $\mathrm{pH} 7.5,10 \mu \mathrm{M}$ 
pyridoxal-5'-phosphate, and $1 \mathrm{mM}$ dithiothreitol) were added. Lysates were cleared by centrifugation at $12000 \times \mathrm{g}$ for $15 \mathrm{~min}$ at $4{ }^{\circ} \mathrm{C}$. The supernatant represented the crude extract. The enzymatic activity of OAS-TL was measured according to Carfagna et al. [20]. The OASTL activity was related to the total soluble protein content of the samples. Protein amounts were determined using the reagent Protein Assay (Bio-Rad Laboratories GmbH, Vienna, Austria) based on the Bradford method [52] with bovine serum albumin as the standard.

\subsection{Plant Mineralization and Mineral Element Analysis}

Aliquots of $0.5 \mathrm{~g}$ of the air-dried roots or leaves were acid digested in a mixture of $6 \mathrm{~mL}$ of $60 \% \mathrm{HNO}_{3}$ and $1 \mathrm{~mL}$ of $30 \% \mathrm{H}_{2} \mathrm{O}_{2}$ at $80{ }^{\circ} \mathrm{C}$ for $40 \mathrm{~min}$. The digestate was filtered and brought up to $50 \mathrm{~mL}$ with ultrapure water (Merk-Millipore Aquatron). The mineral elements were detected by Multi-element measurement in the (ICP-OES) instrument "Inductively Coupled Plasma" Varian Vista [35].

\subsection{Statistical Analysis}

Data were evaluated by analysis of variance (ANOVA) using SPSS Statistics ver. 20. Differences among means were determined using the Scheffè's test. Data are presented as the mean $\pm \mathrm{SD}$ and a value of $p<0.05$ was used to indicate statistical significance. Nearest neighbor clustering with Euclidean distance and Pearson and Spearman correlation coefficients, using the two-tailed test of significance, was also performed to analyze relations among OAS-TL activity, total soluble protein, GSH and GSSG, amino acids, and several metabolites. The results are shown in the Supplementary Materials (Figure S1). Correlation among variables was tested by means of Spearman's rank correlation coefficient. The overall pattern of variations between tissues (roots vs. leaves), salinity, and days of treatment was analyzed by means of a between-group Principal Component Analysis (PCA).

Curves in Figures 2 and 5-7 represent estimates based upon regression analysis of the measured concentrations at 0,3 , and $10 \mathrm{~d}$ using the quadratic equation, $\mathrm{a} x^{2}+\mathrm{b} x+\mathrm{c}$ as a model using Microsoft Excel software, with one exception. In the case of GSH in the roots treated with $100 \mathrm{mM} \mathrm{NaCl}$, the concentration was estimated with the model $\mathrm{a} x+\mathrm{b}$, because modeling with $a x^{2}+b x+c$ produced some slightly negative values for the estimate of GSH concentration between 3 and $10 \mathrm{~d}$.

\subsection{Modelling of Dynamic Concentrations with Regression Analysis}

Using regression analysis to model data taken at different points in time enables estimation of continuous, dynamic aspects of biochemical responses to mild stress by $\mathrm{NaCl}$ from $0 \mathrm{~d}$ through $10 \mathrm{~d}$. The primary data on which statistical data presented in Tables 1-3 are based were used to provide continuous estimates of the concentrations of GSH, GSSG, NADPH, NADP+, Na, and the amino acids GLU, PRO, GLY, SER, TRP, and $\Sigma$ amino acids. Second-order quadratic and first-order linear models were tested, and the quadratic model provided the best fit for all but one of the curves presented in Figures 2 and 5-7. Estimates using the second-order model are based upon regression analysis of the measured, replicated concentrations at 0,3 , and $10 \mathrm{~d}$ using the quadratic equation, $\mathrm{a} x^{2}+\mathrm{b} x+\mathrm{c}$, where $x=$ time measured in days. In the one case where a first-order equation was chosen, GSH in the roots treated with $100 \mathrm{mM} \mathrm{NaCl}$, the concentration was estimated with the model $\mathrm{a} x+\mathrm{b}$, because modeling with $\mathrm{a} x^{2}+\mathrm{b} x+\mathrm{c}$ produced some slightly negative values for the estimate of GSH concentration between 3 and $10 \mathrm{~d}$.

\section{Conclusions}

Salt stress of P. maritimum applied with either $50 \mathrm{mM} \mathrm{NaCl}$ and $100 \mathrm{mM} \mathrm{NaCl}$ treatment, as measured at 3 and $10 \mathrm{~d}$, compared to untreated plants at $0 \mathrm{~d}$, resulted in accumulation of $\mathrm{Na}$ in the roots and relatively little translocation and accumulation of $\mathrm{Na}$ in the leaves. Potassium, $\mathrm{Ca}, \mathrm{Mg}$, and Fe were, on the other hand, translocated from the roots and accumulated at higher concentrations in leaves than in the roots after application of salt stress, as measured at $3 \mathrm{~d}$ and $10 \mathrm{~d}$. Metabolism of P. maritimum in terms of total proteins 
and free amino acids was profoundly affected by salt stress depending on the concentration of $\mathrm{NaCl}$ and the duration of treatment. The simultaneous, large increases in concentrations of amino acids, particularly proline, and the amino acid derivative glycine betaine, indicate production of osmotic compounds in the leaves and roots in response to the large influxes of $\mathrm{Na}$ that was sequestered mainly in the roots. Our results show that OAS-TL activity was affected by salt, appearing after $3 \mathrm{~d}$ of treatment, and disappearing later $(10 \mathrm{~d})$, when other adaptation mechanisms such as higher concentrations of osmotic compounds are evident. Simultaneous synthesis of S-containing compounds, such as glutathione and its constituent amino acids, was supported by photorespiration, which could have a significant function in sulfur metabolism under conditions of osmotic stress due to increased salinity. High concentrations of GSSG and $\mathrm{NADP}^{+}$that accumulated in response to treatment with $\mathrm{NaCl}$ indicate that biosynthesis of glutathione and nicotinamide adenine dinucleotide phosphate are normal, simultaneous responses of P. maritimum to oxidative imbalance resulting from salt stress.

Supplementary Materials: The following are available online at https:/ / www.mdpi.com/2223-774 7/10/2/345/s1, Figure S1: GSH/GSSG ratio in roots (light green) and leaves (brilliant green) tissue of $P$. maritimum plants irrigated with $50 \mathrm{mM}$ (wide striped) and $100 \mathrm{mM}$ (narrow striped) of $\mathrm{NaCl}$ salt solution for 3 and 10 days, Figure S2: Spearman positive correlation of metabolites and OAS-TL activity in P. maritimum under salt treatment (50 and $100 \mathrm{mM}$ ) for 3 and 10 days.

Author Contributions: Conceptualization, S.C., O.D.C., and C.D.M.; methodology, G.S., B.M., and M.I.; writing - original draft preparation, G.S., S.C., C.D.M., and T.W.C.J. All authors have read and agreed to the published version of the manuscript.

Funding: This research received no external funding.

Institutional Review Board Statement: Not applicable.

Informed Consent Statement: Not applicable.

Data Availability Statement: Not applicable.

Conflicts of Interest: The authors declare that the research was conducted in the absence of any commercial or financial relationships that could be construed as a potential conflict of interest.

\section{References}

1. Isayenkov, S.V.; Maathuis, F.J.M. Plant salinity stress: Many unanswered questions remain. Front. Plant Sci. 2019, 10, 80. [CrossRef]

2. Boyer, J.S. Plant productivity and environment. Science 1982, 218, 443-448. [CrossRef]

3. Owens, S. Salt of the earth. Genetic engineering may help to reclaim agricultural land lost due to salinisation. EMBO Rep. 2001, 2, 877-879. [CrossRef]

4. Mishra, A.; Tanna, B. Halophytes: Potential resources for salt stress tolerance genes and promoters. Front. Plant Sci. 2017, 18, 829. [CrossRef] [PubMed]

5. Flowers, T.J.; Colmer, T.D. Salinity tolerance in halophytes. N. Phytol. 2008, 179, 945-963. [CrossRef]

6. Katschnig, D.; Broekman, R.; Rozema, J. Salt tolerance in the halophyte Salicornia dolichostachya Moss: Growth, morphology and physiology. Environ. Exp. Bot. 2013, 92, 32-42. [CrossRef]

7. Fan, C. Genetic mechanisms of salt stress responses in halophytes. Plant Signal. Behav. 2020, 15, 1. [CrossRef] [PubMed]

8. De Castro, O.; Di Maio, A.; Di Febbraro, M.; Imparato, G.; Innangi, M.; Véla, E.; Menale, B. A multi-faceted approach to analyse the effects of environmental variables on geographic range and genetic structure of a perennial psammophilous geophyte: The case of the sea daffodil Pancratium maritimum L. in the Mediterranean Basin. PLoS ONE 2016, 11, e0164816. [CrossRef]

9. De Castro, O.; Innangi, M.; Menale, B. Message in a bottle: The Mediterranean Sea currents acted as protagonists in shaping the distribution of the sea daffodil (Pancratium maritimum, Amaryllidaceae). Bot. J. Linn. Soc. 2020, 194, 207-220. [CrossRef]

10. Pouris, J.; Meletiou-Christou, M.S.; Chimona, C.; Rhizopoulou, S. Seasonal functional partitioning of carbohydrates and proline among plant parts of the sand daffodil. Agronomy 2020, 10, 539. [CrossRef]

11. Glenn, E.P.; Brown, J.J.; Blumwald, E. Salt tolerance and crop potential of halophytes. Critical Rev. Plant Sci. 1999, 18, 227-255. [CrossRef]

12. Khan, N.A.; Khan, M.I.R.; Asgher, M.; Fatma, M.; Masood, A.; Syeed, S. Salinity tolerance in plants: Revisiting the role of sulfur metabolites. J. Plant Biochem. Physiol. 2014, 2, 120.

13. Manchanda, G.; Garg, N. Salinity and its effect on the functional biology of legumes. Acta Physiol. Plant. 2008, 30, 595-618. [CrossRef] 
14. Nazar, R.; Iqbal, N.; Syeed, S.; Khan, N.A. Salicylic acid alleviates decreases in photosynthesis under salt stress by enhancing nitrogen and sulfur assimilation and antioxidant metabolism differentially in two mungbean cultivars. J. Plant Physiol. 2011, 168, 807-815. [CrossRef]

15. Leustek, T. Sulfate metabolism. Arab. Book 2002, 1, e0017. [CrossRef]

16. Salbitani, G.; Vona, V.; Bottone, C.; Petriccione, M.; Carfagna, S. Sulfur deprivation results in oxidative perturbation in Chlorella sorokiniana (211/8k). Plant Cell Physiol. 2015, 56, 897-905. [CrossRef] [PubMed]

17. Carfagna, S.; Bottone, C.; Cataletto, P.R.; Petriccione, M.; Pinto, G.; Salbitani, G.; Vona, V.; Pollio, A.; Ciniglia, C. Impact of sulfur starvation in autotrophic and heterotrophic cultures of the Extremophilic Microalga Galdieria phlegrea (Cyanidiophyceae). Plant Cell Physiol. 2016, 57, 1890-1898. [CrossRef]

18. Cao, M.J.; Wang, Z.; Zhao, Q.; Mao, J.L.; Speiser, A.; Wirtz, M.; Hell, R.; Zhu, J.K.; Xiang, C.B. Sulfate availability affects ABA levels and germination response to ABA and salt stress in Arabidopsis thaliana. Plant J. 2014, 77, 604-615. [CrossRef] [PubMed]

19. Fediuc, E.; Lips, S.H.; Erdei, L. O-acetylserine(thiol)lyase activity in Phragmites and Typha plants under cadmium and NaCl stress conditions and the involvement of ABA in the stress response. J. Plant Physiol. 2005, 162, 865-872. [CrossRef]

20. Carfagna, S.; Vona, V.; Di Martino, V.; Esposito, S.; Rigano, C. Nitrogen assimilation and cysteine biosynthesis in barley: Evidence for root sulphur assimilation upon recovery from $\mathrm{N}$ deprivation. Environ. Exp. Bot. 2011, 71, 18-24. [CrossRef]

21. Speiser, A.; Haberland, S.; Watanabe, M.; Wirtz, M.; Dietz, K.J.; Saito, K.; Hell, R. The significance of cysteine synthesis for acclimation to high light conditions. Front. Plant Sci. 2015, 5, 776. [CrossRef]

22. Dumanović, J.; Nepovimova, E.; Natić, M.; Kuča, K.; Jaćevic, V. The significance of reactive oxygen species and antioxidant defense system in plants: A concise overview. Front. Plant Sci. 2021, 11, 552969. [CrossRef] [PubMed]

23. Ma, B.; Suo, Y.; Zhang, J.; Xing, N.; Gao, Z.; Lin, X.; Zheng, L.; Wang, Y. Glutaredoxin like protein (RtGRL1) regulates $\mathrm{H}_{2} \mathrm{O}_{2}$ and $\mathrm{Na}^{+}$accumulation by maintaining the glutathione pool during abiotic stress. Plant Physiol. Biochem. 2021, 159, 135-147. [CrossRef]

24. Schaedle, M.; Bassham, J.A. Chloroplast glutathione reductase. Plant Physiol. 1977, 59, 1011-1012. [CrossRef]

25. Connell, J.P.; Mullet, J.E. Pea chloroplast glutathione reductase: Purification and characterization. Plant Physiol. 1986, 82, 351-356. [CrossRef] [PubMed]

26. Chen, Y.P.; Xing, L.P.; Wu, G.J.; Wang, H.Z.; Wang, X.E.; Cao, A.Z.; Chen, P.D. Plastidial glutathione reductase from Haynaldia villosa is an enhancer of powdery mildew resistance in wheat (Triticum aestivum). Plant Cell Physiol. 2007, 48, 1702-1712.

27. Carfagna, S.; Vona, V.; Salbitani, G.; Sorbo, S.; Lanza, N.; Conte, B.; Di Martino-Rigano, V.; Castaldo-Cobianchi, R.; Golia, B.; Basile, A. Cysteine synthesis in Scorpiurum circinatum as a suitable biomarker in air pollution monitoring. Int. J. Environ. Health 2011, 5, 93-105. [CrossRef]

28. Salbitani, G.; Hell, R.; Wirtz, M.; Carfagna, S. Affinity purification of O-acetylserine(thiol)lyase from Chlorella sorokiniana by recombinant proteins from Arabidopsis thaliana. Metabolites 2014, 4, 629-639. [CrossRef]

29. De Castro, O.; Innangi, M.; Menale, B.; Carfagna, S. O-acetylserine(thio)lyase (OAS-TL) molecular expression in Pancratium maritimum L. (Amaryllidaceae) under salt stress. Planta 2018, 247, 773-777. [CrossRef] [PubMed]

30. Mittler, R. Oxidative stress, antioxidants and stress tolerance. Trends Plant Sci. 2002, 7, 405-410. [CrossRef]

31. Doganlar, Z.B.; Demir, K.; Basak, H.; Gul, I. Effects of salt stress on pigment and total soluble protein contents of three different tomato cultivars. Afr. J. Agric. Res. 2010, 5, 2056-2065.

32. Morant-Avice, A.; Pradier, E.; Houchi, R. Osmotic adjustment in triticales grown in presence of NaCl. Biol. Plant. 1998, 41, 227-234. [CrossRef]

33. Wu, H.; Zhang, X.; Giraldo, J.P.; Sergey, S. It is not all about sodium: Revealing tissue specificity and signalling roles of potassium in plant responses to salt stress. Plant Soil 2018, 431, 1-17. [CrossRef]

34. Rozov, A.; Khusainov, I.; El Omari, K.; Duman, R.; Mykhaylyk, V.; Yusupov, M.; Westhof, E.; Wagner, A.; Yusupova, G. Importance of potassium ions for ribosome structure and function revealed by long-wavelength $\mathrm{X}$-ray diffraction. Nat. Commun. 2019, 10, 2519. [CrossRef]

35. Di Martino, C.; Delfine, S.; Pizzuto, R.; Loreto, F.; Fuggi, A. Free amino acids and glycine betaine in leaf osmoregulation of spinach responding to increasing salt stress. New Phyt. 2003, 158, 455-463. [CrossRef]

36. Loupassaki, M.H.; Chartzoulakis, K.S.; Digalaki, N.B.; Androulakis, I.I. Effects of salt stress on concentration of nitrogen, Phosphorus Potassium, Calcium, Magnesium and sodium in leaves, shoots and roots of six olive cultivars. J. Plant Nut. 2002, 25, 2457-2482. [CrossRef]

37. Wallace, A.; Mueller, R.T. Calcium uptake and distribution in plants. J. Plant Nut. 1980, 2, 247-256. [CrossRef]

38. Sonnevelt, C.; van den Ende, J. The effects of some salts on head weight and tipburn of lettuce and on fruit production and blossom end rot of tomatoes. Neth. J. Agric. Sci. 1975, 23, 192-201.

39. Munns, R.; Tester, M. Mechanisms of salinity tolerance. Annu. Rev. Plant Biol. 2008, 59, 651-681. [CrossRef] [PubMed]

40. Tavakkoli, E.; Fatehi, F.; Coventry, S.; Rengasamy, P.; McDonald, G. Additive effects of $\mathrm{Na}^{+}$and $\mathrm{Cl}^{-}$ions on barley growth under salinity stress. J. Exp. Bot. 2011, 62, 2189-2203. [CrossRef]

41. Dhaliwal, S.; Naresh, R.K.; Mandal, A.; Singh, R.; Dhaliwal, M.K. Dynamics and transformations of micronutrients in agricultural soils as influenced by organic matter build-up: A review. Environ. Sustain. Indic. 2019, 1, 100007. [CrossRef]

42. Curie, C.; Briat, J.F. Iron transport and signaling in plants. Annu. Rev. Plant Biol. 2003, 54, 183-206. [CrossRef]

43. Babaeian, M.; Esmaeilian, Y.; Tavassoli, A.; Asgharzade, A.; Sadeghi, M. The effects of water stress, manure and chemical fertilizer on grain yield and grain nutrient content in barley. SRE 2011, 6, 3697-3701. 
44. Tanveer, M.; Ahmed, H.A.I. ROS signalling in modulating salinity stress tolerance in plants. In Salt and Drought Stress Tolerance in Plants—Signaling and Communication in Plants; Hasanuzzaman, M., Tanveer, M., Eds.; Springer: Cham, Switzerland, 2020.

45. Ribba, T.; Garrido-Vargas, F.; O’Brien, J.A. Auxin-mediated responses under salt stress: From developmental regulation to biotechnological applications. J. Exp. Bot. 2020, 71, 3843-3853. [CrossRef] [PubMed]

46. Verbruggen, N.; Hermans, C. Proline accumulation in plants: A review. Amino Acids 2008, 35, 753-759. [CrossRef]

47. Ashraf, M.; Harris, P.J.C. Potential biochemical indicators of salinity tolerance in plants. Plant Sci. 2004, 166, 3-16. [CrossRef]

48. Verslues, P.E.; Sharma, S. Proline metabolism and its implications for plant-environment interaction. Arab. Book 2010, 8, e0140. [CrossRef]

49. Carfagna, S.; Salbitani, G.; Vona, V.; Esposito, S. Changes in cysteine and O-acetyl-L-serine levels in the microalga Chlorella sorokiniana in response to the S-nutritional status. J. Plant Physiol. 2011, 168, 2188-2195. [CrossRef]

50. Hoagland, D.R.; Arnon, D.I. The water-culture method for growing plants without soil. Calif. Agric. Exp. Stn. Circ. 1950, $347,1-32$.

51. Di Martino, C.; Pallotta, M.L. Mitochondria-localized NAD biosynthesis by nicotinamide mononucleotide adenylyltransferase in Jerusalem artichoke (Helianthus tuberosus L.) heterotrophic tissues. Planta 2011, 234, 657-670. [CrossRef]

52. Bradford, M.M. Rapid and sensitive method for the quantitation of microgram quantities of protein utilizing the principle of protein-dye binding. Anal. Biochem. 1976, 72, 248-254. [CrossRef] 